\title{
DEVELOPMENT OF A GLIAL NETWORK IN THE OLFACTORY NERVE: ROLE OF CALCIUM AND NEURONAL ACTIVITY
}

by

\author{
Mounir Ahmad Koussa
}

\begin{abstract}
A Thesis submitted to the Honors College
in partial fulfillment of the requirements for the Honors Degree in

Biochemistry, Molecular Biophysics and Chemistry

The University of Arizona
\end{abstract}

May 2011

Approved by:
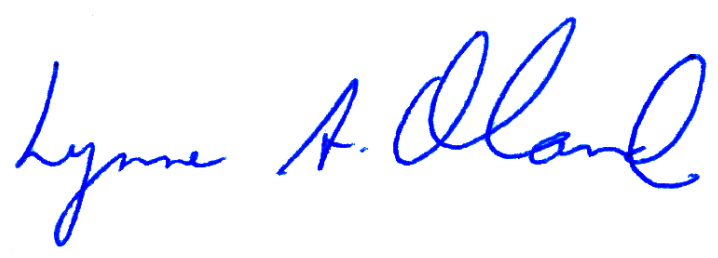

Lynne A. Oland, Ph.D.

Research Professor

Department of Neuroscience 


\section{STATEMENT BY THE AUTHOR}

This thesis has been submitted in partial fulfillment for a degree at The University of Arizona and is deposited in the University Library to be made available to borrowers under the rules of the Library.

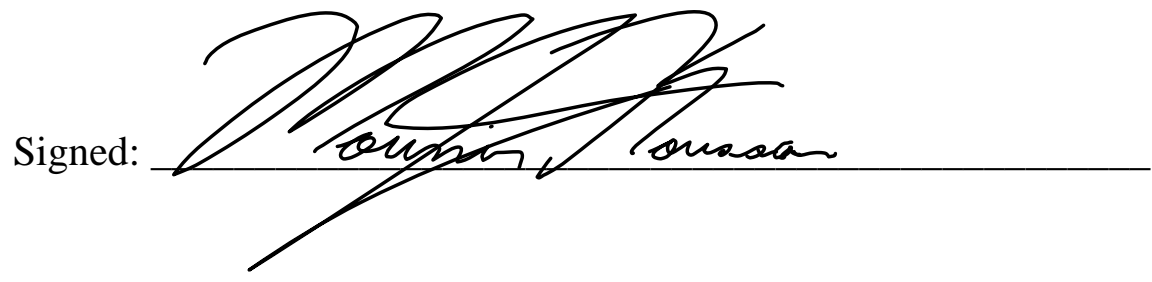




\section{ACKNOWLEDGEMENTS}

I would like express my gratitude for the people who have helped make this project possible. Dr. Lynne A. Oland is an amazing mentor who always puts her students first. She has treated me with respect and given me the freedom to grow as a scientist. I have learned many things from Dr. Oland. She has taught me numerous laboratory techniques, she has improved my grammar drastically, she has helped me overcome academic and personal issues, and she has taught me how to think like a scientist. I would also like to extend my thanks to Dr. Leslie P. Tolbert for her support over the past four years. I would like to thank Dr. Nicholas J. Gibson and Ms. Patricia Jansma for their technical advice and willingness to help me when I encountered problems. I also wish to thank all of the members of the lab for being amazing colleagues who have been a great pleasure to work with and from whom I have learned a lot. The past four years in the lab have been amazing to say the least, I cannot begin to express the impact you have all had on my life. I am going to miss you all greatly now that I am leaving but I will always have roots here in Tucson so I will be back to visit the lab soon. 


\section{TABLE OF CONTENTS}

Abstract.......................................................... 4

Introduction................................................... 5

Methods.......................................................... 8

Results and Figures............................................ 16

Discussion..................................................... 31

Acknowledgements............................................ 42

References....................................................... 43 


\section{Abstract}

In the adult olfactory nerves of both mammals and moths, a network of glial cells ensheathes bundles of $60-80$, small-diameter $(0.1 \mu \mathrm{m})$ olfactory receptor axons. In the developing olfactory (antennal) nerve (AN) of the moth Manduca sexta, the axons of olfactory receptor neurons (ORNs) grow from the olfactory sensory epithelium toward the olfactory lobe, and glial cells from the olfactory epithelium migrate in long chains behind and along the axons. The AN glial cells are highly dye coupled at early stages in this process. At early stages of development (Stages 6-9) roughly $3 \%$ of the glial cells are dividing while only $0.2 \%$ of the cells are dividing by stage 12. The AN glial cells label strongly for glutamine synthetase at stages 6 and 7 , however staining of glutamine synthetase labeling in the AN glia steadily decreased between stages 7 and 12 while labeling in the centrally derived neuropil glial cells in the olfactory (antennal) lobe (AL) remained strong. Whole-cell recordings in vivo from AN glia at different stages of network formation revealed both a 4-AP-sensitive potassium current and 4-APinsensitive potassium current. Perforated-patch recordings from these glia revealed an SNX-482 sensitive R-like calcium current. Chronic exposure to SNX-482 in vivo halted the migration of the antennal nerve glial cells. Extracellular recordings from the AN during the period of axon ingrowth reveal spontaneous Na-dependent activity that can be silenced chronically by injection of TTX. While acute bath exposure to TTX in vivo showed no effect on the glial calcium current, recordings from glial cells in the ANs of animals chronically exposed to TTX in vivo during the period of axon ingrowth showed a reduction in the calcium current amplitude from $\sim 600 \mathrm{pA}$ to $\sim 200 \mathrm{pA}$, implicating an activity-dependent interaction between ORNs and glial cells in the development of glial calcium currents. 


\section{Introduction}

Glial cells are involved in dynamic interactions with neurons not only in the adult nervous system but also in the developing nervous system. Glial cells have been shown in both vertebrates and invertebrates to affect numerous processes, including neurogenesis, synaptogenesis, axon growth, fasciculation, and targeting, synapse maintenance and removal, synaptic function, and dendritic pruning.

A longstanding focus of the laboratory has been glial involvement in formation of the well conserved olfactory pathway. Olfactory systems have several populations of glial cells, each with specific functions that are required for normal development. For example, in the developing olfactory pathway of the moth Manduca sexta, centrally derived glial cells are key players in the navigation of olfactory receptor axons to their targets in the developing brain (Oland et al., 2010; Rössler et al., 1999) and in the construction of glomerular compartments in the olfactory lobe (Oland et al., 1990) as they are in the rodent (Treloar et al., 1999; Au et al., 2002; Bailey and Shipley, 1999). Development of the normal adult repertoire of ion channels in neuropil glial cells of the olfactory lobe requires the presence of olfactory receptor neurons. Importantly, these developmental processes typically depend on reciprocal signaling between the two cellular classes.

Here we turn to an examination of peripheral glial cells that arise in the olfactory sensory epithelium with the goal of understanding developmental conversations between ingrowing receptor axons and the glial cells that eventually form a complex three-dimensional network that 
ensheathes bundles of axons. The final spatial distribution of the peripherally derived glial cells in the M. sexta olfactory pathway is well understood (Sanes and Hildebrand, 1976), the morphological organization of the nerve vis-à-vis axonal bundling closely resembling the vertebrate olfactory nerve (Kreutzberg and Gross, 1977; Doucette, 1984; Barber and Lindsay, 1982). Although our approach includes examination of network development using several markers in fixed tissue, a major objective was to probe the intact nerve electrophysiologically in order to examine glial-neuronal interactions in the three-dimensional and signaling context characteristic of the normal environment. The olfactory (antennal) nerve of the moth is ideal for this study in that it is a large, easily accessible structure in which the centrally and peripherally derived glial populations can be easily distinguished by position in the nerve, and in which migration and division can be monitored easily throughout development. The glial cells populating the antennal nerve derive from the olfactory epithelium and are similar in many respects to the olfactory ensheathing cells in the olfactory nerve of mammals ( $\mathrm{Su}$ and $\mathrm{He}, 2010$ ).

Another key question is whether formation of the glial network in the moth nerve depends on the presence or activity of olfactory sensory neurons. We know that when peripheral nerve glial cells are grown in the presence of olfactory receptor neurons (ORNs), they form multi-cellular arrays that are reminiscent of the ensheathing glial networks in the normal nerve (Tucker and Tolbert, 1993). The tendency of glial cells to form networks falls off with distance from explants of ORNs and is not contact-dependent, suggesting a diffusible signal acting locally between the glial cells and the ORNs. In other systems, signaling between axons and glial cells can be mediated by transmitters such as glutamate and ATP released from the axons and eliciting an increase in cytosolic calcium in the glial cells (Lohr et al., 2005 and van den Pol et al., 1992). 
Electrical stimulation of the antennal nerve in Manduca induces an increase in intracellular calcium in central glial cells in the antennal lobe (Lohr et al., 2005a,b). Blocking this increase in vivo reduces the migration of these neuropil-associated glial cells, raising the possibility that stimulation-induced increase in calcium also mediates migration of peripheral glial cells.

In this study, we show that the development of the antennal nerve glial network involves glial migration, process extension, and proliferation, that the glial cells have both potassium and calcium currents, that blocking the glial R-like calcium current blocks migration of the peripheral glial cells, and that normal development of the calcium current depends on neuronal activity.

\section{Methods}

\section{Animals and Preparation}

Manduca sexta (Lepidoptera: Sphingidae) were reared in the departmental insect-rearing facility under a long-day photoperiod as described previously (Oland and Tolbert, 1987). Metamorphic development starts with pupation and ends with the emergence of the moth after passing through 18 stages, each lasting about a day. Pupae were staged by following changes of structures that are visible under the pupal cuticle (Oland and Tolbert, 1987). Before dissection of the brain, pupae were anesthetized by cooling on ice or by exposure to $\mathrm{CO}_{2}$ for at least $30 \mathrm{~min}$. The brains then were dissected quickly from the head and placed in cold dissecting solution (see Solutions, below) where the olfactory pathway was isolated from the remainder of the brain and the perineural sheath was removed. Post isolation and removal of sheath, a drop of dissecting solution including a lobe was transferred onto a glass cover slip in a dish containing recording saline (see Solutions, below). 


\section{Solutions}

The following solutions were adjusted to $\mathrm{pH} 7.0$ and an osmolarity of 370-375 mOsm unless otherwise noted.

Physiology solutions

AIS (An Insect Saline): $150 \mathrm{mM} \mathrm{NaCl}, 4 \mathrm{mM} \mathrm{KCl}, 6 \mathrm{mM} \mathrm{CaCl} 2,10 \mathrm{mM}$ HEPES buffer, $5 \mathrm{mM}$ glucose, 360 mOsm. Dissecting Solution: 27\% L-15, 53\% AIS, 20\% Culture Chow, 1.7g/L glucose. Recording Saline: 150mM NaCl, 4mM KCl, 6 mM CaCl $2,10 \mathrm{mM}$ HEPES buffer, 5 $\mathrm{mM}$ glucose, $\mathrm{pH}$ 6.8. $\mathbf{B a C l}_{\mathbf{2}}$ Recording Saline: Standard recording saline with $2 \mathrm{mM} \mathrm{BaCl}_{2}$ and $4 \mathrm{mM} \mathrm{MgCl}_{2}$ substituting for $6 \mathrm{mM} \mathrm{CaCl}_{2}$ K-free, 4-AP containing $\mathbf{B a C l}_{\mathbf{2}} \mathbf{R e c o r d i n g}_{\mathbf{A a l i n e}}$ 144mM NaCl, 6 mM BaCl 2,10 mM HEPES buffer, 10 mM 4-AP, 5 mM glucose, pH 6.8. 4-AP(4-Amino Pyridine) Recording Saline: 140mM NaCl, 4mM KCl, $6 \mathrm{mM} \mathrm{CaCl} 2,10 \mathrm{mM}$ HEPES buffer, $10 \mathrm{mM}$ 4-AP, $5 \mathrm{mM}$ glucose, $\mathrm{pH}$ 6.8. Low Ca, 4-AP Recording Saline: Standard recording saline with $0.6 \mathrm{mM} \mathrm{CaCl}_{2}, 5.4 \mathrm{mM} \mathrm{MgCl} 2$ substituting for $6 \mathrm{mM} \mathrm{CaCl} 2, \mathrm{pH}$ 6.8. Low Ba-Ba sub, 4-AP Recording Saline: $140 \mathrm{mM} \mathrm{NaCl}, 4 \mathrm{mM} \mathrm{KCl}, 0.6 \mathrm{mM} \mathrm{BaCl} 2,10$ $\mathrm{mM}$ HEPES buffer, $10 \mathrm{mM}$ 4-AP, $5 \mathrm{mM}$ glucose, $\mathrm{pH}$ 6.8. Pipette Solution: $150 \mathrm{mM} \mathrm{K}$ aspartate, $8 \mathrm{mM} \mathrm{NaCl}, 2 \mathrm{mM} \mathrm{MgCl} 2,1 \mathrm{mM} \mathrm{CaCl}_{2}, 11 \mathrm{mM}$ EGTA, $2 \mathrm{mM}$ ATP, and $0.01 \mathrm{mg} / \mathrm{ml}$ Lucifer Yellow lithium salt. TEA (tetraethyl-ammonium) Pipette Solution: $120 \mathrm{mM} \mathrm{K}$ aspartate, $8 \mathrm{mM} \mathrm{NaCl}, 2 \mathrm{mM} \mathrm{MgCl} 2,1 \mathrm{mM} \mathrm{CaCl} 2,11 \mathrm{mM}$ EGTA, $2 \mathrm{mM}$ ATP, $30 \mathrm{mM}$ TEA, and $0.01 \mathrm{mg} / \mathrm{ml}$ Lucifer Yellow lithium salt. Cs Pipette Solution: Standard pipette solution with $150 \mathrm{mM}$ Cs aspartate substituted for $\mathrm{K}$ aspartate. 


\section{Culture solutions}

Culture saline (Oland et al.,1996). $149.9 \mathrm{mM} \mathrm{NaCl}, 3 \mathrm{mM} \mathrm{KCl}, 3 \mathrm{mM} \mathrm{CaCl} 2,0.5 \mathrm{mM} \mathrm{MgCl}_{2}$, 10 mM TES, 11 mM D-glucose, 3 g/liter lactalbumin hydrosylate (11800-026; Gibco), 2.5 g/liter TC yeastolate (255772; Difco, Detroit, MI), 5\% fetal bovine serum (FBS; Hyclone, Logan, UT), $100 \mathrm{U} / \mathrm{ml}$ penicillin, and $100 \mu \mathrm{g} / \mathrm{ml}$ streptomycin, osmolarity adjusted to $360 \mathrm{mOsm}$ with mannitol. Culture medium (supplemented Leibovitz's L-15 culture medium; Lohr et al., 2002). The following ingredients were added to $492 \mathrm{ml}$ of L-15: $25 \mathrm{ml}$ fetal bovine serum (FBS), 185 mg $\alpha$-ketoglutaric acid, $200 \mathrm{mg}$ D-(-)-fructose, $350 \mathrm{mg}$ D-glucose, $335 \mathrm{mg}$ DL-malic acid, 30 $\mathrm{mg}$ succinic acid, $1.4 \mathrm{~g}$ lactalbumin hydrosylate, $1.4 \mathrm{~g}$ TC yeastolate, $0.1 \mathrm{mg}$ niacin, $30 \mathrm{mg}$ imidazole, $500 \mu \mathrm{g}$ 20-hydroxyecdysone (H5142; Sigma), $100 \mathrm{U} / \mathrm{ml}$ penicillin, $100 \mu \mathrm{g} / \mathrm{ml}$ streptomycin, $5 \mu \mathrm{g} / \mathrm{ml}$ insulin, $290 \mu \mathrm{g} / \mathrm{ml}$ glutamine, $200 \mu \mathrm{g} / \mathrm{ml}$ cysteine, $110 \mu \mathrm{g} / \mathrm{ml}$ pyruvate, and $2.5 \mathrm{ml}$ stable vitamin mix (SVM). A 5-ml stock solution of SVM consisted of $15 \mathrm{mg}$ aspartic acid, $15 \mathrm{mg}$ cystine, $5 \mathrm{mg} \beta$-alanine, $0.02 \mathrm{mg}$ biotin, $2 \mathrm{mg}$ vitamin B12, $10 \mathrm{mg}$ inositol, $10 \mathrm{mg}$ choline chloride, $0.5 \mathrm{mg}$ lipoic acid, $5 \mathrm{mg}$ p-aminobenzoic acid, $25 \mathrm{mg}$ fumaric acid, $0.4 \mathrm{mg}$ coenzyme A, $15 \mathrm{mg}$ glutamic acid, and $100 \mathrm{ml}$ of the supplemented L-15 before the FBS, SVM, 20-HE and penicillin/streptomycin are added. The osmolarity was raised to $375 \mathrm{mOsm}$ with Dglucose prior to sterile filtration. Simple salt solution. $160 \mathrm{mM} \mathrm{NaCl,} 6 \mathrm{mM} \mathrm{KCl,} 78.8 \mathrm{mM}$ Dglucose, $10 \mathrm{mM}$ HEPES, $100 \mathrm{U} / \mathrm{ml}$ penicillin, and $100 \mu \mathrm{g} / \mathrm{ml}$ streptomycin. Recovery solution. $50 \%(\mathrm{v} / \mathrm{v})$ culture saline and 50\% (v/v) simple salt solution, 390 mOsm. Dissecting medium. The following ingredients were used: 50\% Leibovitz's L-15 (41300-039; Gibco), 25\% (v/v) culture saline, $25 \%$ simple salt solution with $5 \mathrm{mM}$ EDTA, and $18 \mathrm{mM}$ D-glucose. 


\section{Whole-Cell and Perforated-Patch-Clamp Recording}

Preparations were transferred into a recording chamber (volume approximately $1 \mathrm{ml}$ ) and fixed in place using a U-shaped stainless steel frame laced with nylon strings. The recording chamber was mounted on the fixed stage of an upright microscope (Axioskop FS; Zeiss, Oberkochen, Germany). A motorized three-axis micromanipulator (model 460A; Newport Corporation, Irvine, CA) was mounted beside the microscope. The microscope was equipped with infrared (infrared condenser filter RG715; A.G. Heinz) and fluorescence optics, a CCD video camera (C2400; Hamamatsu, infrared filter removed), and a water-immersion objective lens (Zeiss Achroplan 403, NA 0.75 , working distance $2 \mathrm{~mm}$ ). Patch pipettes were pulled from thin-walled borosilicate glass capillary tubes (TW150-3; World Precision Instruments, Sarasota, FL) with a vertical puller (Type PP-83; Narishige, Japan). The whole-cell pipettes were filled with the pipette solution directly before an experiment and had resistances of 8-10 M $\Omega$. Perforated-patch pipettes

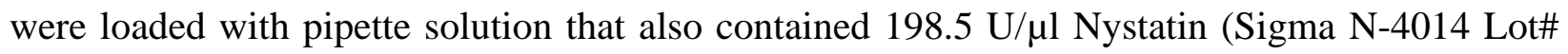
114K8315 or MP Biomedicals 194534 Lot\# 3029KA) and had resistances of 6-8 M $\Omega$. Wholecell and perforated-patch currents were recorded with an Axopatch 200B amplifier (Axon Instruments) and digitized using a Digidata 1440A (Axon Instruments). Current signals were filtered with a lowpass Bessel filter at $1 \mathrm{kHz}$. Data acquisition and analysis were done using pClamp 10 software (Axon Instruments). Leak currents were subtracted online using a p/4 protocol. Two runs per trial were averaged, and only the averaged traces were stored and analyzed. For morphological investigations, whole-cell pipettes were filled with Lucifer Yellowfilled cells as described previously (Oland et al., 1999) and imaged using Zeiss 510 Meta laser scanning confocal microscope. 


\section{Data Analysis}

Current amplitudes were measured at the end of either a 100-ms voltage step or a 1000-ms voltage train. I-V plots were made at the maximal amplitude and the minimum after inactivation if applicable. Current traces of pharmacologically treated cells were subtracted from the recordings taken before the application of the pharmacological agent to determine the nature of the current sensitive to the agent.

\section{Immunocytochemistry}

\section{Phospho-Histone H3}

Glial cell proliferation was assessed by monitoring DNA synthesis by means of labeling exposed phosphor-histone $\mathrm{H} 3$ molecules. Brains were dissected at the stage of interest and immediately placed in a $4 \%$ parafomaldehyde in $0.1 \mathrm{M}$ PO4 buffer fixation solution $48 \mathrm{hrs}$ at $4 \mathrm{oC}$ on a shaker. After fixation brains were washed with phosphate buffered saline (PBS) then rinsed three times (10 min each), embedded in 7\% low-melting-point agarose, and serially sectioned in the frontal plane with a vibratome at $75-\mu \mathrm{m}$ thickness. Sections were subsequently incubated in PBS with $40 \mathrm{U} / \mathrm{ml}$ DNase and $4 \mathrm{mM} \mathrm{MgCl} 2$ for an hour at 37o $\mathrm{C}$ followed by a 45 min permeabilization in $2 \%$ normal goat serum (NGS) in PBS with $0.5 \%$ Triton X-100 (0.5\% PBST). The sections were then incubated in anti-phospho-histone H3 (Sigma H0412-200UL Lot\# 092K4804) at 1:300 in $0.5 \%$ PBST with $2 \%$ NGS overnight on a shaker at room temperature. The sections were then washed three times (10 min each) with $0.1 \%$ PBST before incubating for four hours in goat antirabbit F(ab)2-Cy3(Jackson Immuno Research Laboratories 111-166-047 Lot\# 93574) 1:200 in 0.1\% PBST. Post incubation in secondary the sections were washed once for $10 \mathrm{~min}$ in $0.1 \%$ PBST and twice (10 min each) in $10 \mathrm{mM}$ trisbuffer (TB) before incubating for an hour in Syto- 
59 (Invitrogen S11341 Lot\# 695905) at 1:10,000 in TB. Post Syto-59 staining sections were rinsed in $\mathrm{TB}$ for $10 \mathrm{~min}$ before washing for $15 \mathrm{~min}$ in 50:50 glycerol:water then again for $15 \mathrm{~min}$ in 80:20 glycerol:water before mounting in 80:20 glycerol:water.

\section{Glutamine synthetase}

Brains were microwave-fixed (Pelco) under vacuum in $600 \mu$ of fixative solution $(1.34 \mathrm{mM}$ sodium cacodylate, $0.53 \mathrm{mM}$ sodium metabisulfate (SMB), $2.56 \%$ paraformaldehyde, and $0.96 \%$ glutaraldehyde, $\mathrm{pH}$ adjusted to 7.2 with HCL) at Power 2 for the sequence 2 min on, 2 min off, 2 min on, 2 min off. The brains were placed in fresh fixative solution $\mathrm{ON}$ on a shaker at $4^{\mathrm{O}} \mathrm{C}$. Brains were then rinsed in $0.05 \mathrm{M}$ Tris- $\mathrm{HCl}$ followed by $15 \mathrm{~min}$ in sodium borohydride $(0.01 \mathrm{M}$ $\mathrm{NaBH}_{4}, 0.5 \mathrm{wt} \% \mathrm{SMB}$, and $0.05 \mathrm{M}$, and $0.05 \mathrm{M}$ Tris-HCl. After washing $3 \times 10 \mathrm{~min}$ in PBS, they were embedded in $7 \%$ low-melting-point agarose and sectioned to $75 \mu \mathrm{m}$ using a vibratome. Sections were washed $3 \times 20 \mathrm{~min}$ in TBS, incubated $20 \mathrm{~min}$ in $2 \mathrm{~N} \mathrm{HCL}$ in $0.1 \mathrm{M} \mathrm{PO}_{4}$, washed $3 \mathrm{x}$ 10 min in TBS, blocked for $2 \mathrm{hrs}$ in TBS with 5\% IgG-free BSA and $0.3 \%$ Triton, and incubated $\mathrm{ON}$ at $4^{\mathrm{O}} \mathrm{C}$ in TBS with 1:100 anti-glutamine synthetase (BD Transduction Laboratories 610518 Lot\# 37506), $1 \%$ IgG-free BSA, and 0.1\% Triton. Sections were washed in TBS with $0.3 \%$ Triton 4 x 30 min, then incubated in goat anti-mouse Fab'-Alexa 488 (Invitrogen A11017 Lot\# 54254A) at 1:400 in TBS with $0.1 \%$ Triton for $2 \mathrm{hrs.} \mathrm{Sections} \mathrm{were} \mathrm{then} \mathrm{washed} \mathrm{in} \mathrm{TBS} 2 \times 10$ min, then in $0.1 \mathrm{M}$ Tris buffer 3 x 5 minutes followed by a 45- min incubation in 1:5000 syto-59 (Invitrogen S11341 Lot\# 695905) in 0.1M Tris buffer, washed $2 \times 5$ min in 0.1M Tris buffer and cleared in 50\% glycerol in water for $15 \mathrm{~min}$, then mounted in $80 \%$ glycerol. 


\section{SYTO staining}

To reveal the position of glial cells, tissue was stained with the nucleic acid stains, Syto 13 (Invitrogen S7575 Lot\# 24508W) or Syto 59 (Invitrogen S11341 Lot\# 695905). After washing off the fixative solution in preparations only stained with Syto or after completing the secondary antibody step in immunocytochemistry protocols, the tissue was washed with $0.1 \mathrm{M}$ Tris buffer 2 x 5-10 min, incubated in Syto at1:5000 in Tris buffer for $3 \mathrm{hrs,} \mathrm{then} \mathrm{washed} \mathrm{in} \mathrm{Tris} \mathrm{buffer} 5 \times 10$ min, then cleared and mounted in glycerol as above.

\section{TTX}

To measure the effects of TTX inhibition of neuronal activity on the development of calcium currents in antennal nerve glial cells, st- 6 male animals were injected with $20 \mu 1$ of a stock $1 \times 10^{-2}$ M TTX solution ((Calbiochem 554412 Lot\# D0082298 and D0089323) and dissected at stage 9. Assuming an approximately 2-ml volume for the animal (Morton and Truman, 1985), this would result in a $1 \times 10^{-4} \mathrm{M}$ final TTX. At dissection, half of the brain was placed in $4 \%$ paraformaldehyde in $0.1 \mathrm{M} \mathrm{PO}_{4}$ at $4^{\circ} \mathrm{C}$ for subsequent Syto 13 labeling, as above; the other half was prepared for perforated-patch recording from the AN glial cells.

\section{SNX}

Acute application of SNX-482 for electrophysiological recordings was performed as follows. The perfusion of saline was halted leaving approximately $1 \mathrm{ml}$ of saline in the chamber. $10 \mu \mathrm{L}$ of $10 \mu \mathrm{M}$ SNX-482 in $\mathrm{H}_{2} \mathrm{O}$ were pipetted into the chamber resulting in a final SNX-482 concentration of $0.1 \mu \mathrm{M}$. The SNX-482 was allowed to sit for 10 minutes before resuming perfusion with saline. In vivo exposure to SNX-482 consisted of injecting $10 \mu \mathrm{L}$ of $10 \mu \mathrm{M}$ SNX482 into the headspace at stage 4 , stage 5 , and stage 6 . Animals were dissected 12 hours post 
final injection. In vitro exposure to SNX-482 consisted of the addition of 1 or10 $\mu \mathrm{L}$ of $10 \mu \mathrm{M}$ SNX-482 to a total volume of $1 \mathrm{ml} 4$ hours post plating of glial cells which were plated 24 hours after ORN explants (Tucker E and Tolbert LP, 2003).

\section{Cultures}

Co-cultures of antennal nerve glial cells and antennal explants were made exactly as reported by Tucker and Tolbert (2003).

\section{Electron Microscopy}

Moths were anesthetized, and the brains were dissected free from the surrounding tissue. Brains were fixed overnight in $0.5 \%$ paraformaldehyde, $2.5 \%$ glutaraldehyde, $0.002 \% \mathrm{CaCl}_{2}, 7.5 \mathrm{mg} / \mathrm{ml}$ sucrose solution in $0.1 \mathrm{M}$ phosphate buffer and then rinsed two times (10 min each) in $0.1 \mathrm{M}$ phosphate buffer. The brains were then incubated in $1 \% \mathrm{OsO} 4$ in $0.1 \mathrm{M} \mathrm{PO}_{4}$ buffer for $3-4 \mathrm{hrs}$, then were rinsed in $0.1 \mathrm{M} \mathrm{PO}_{4}$ buffer $2 \times 15 \mathrm{~min}$, after which they were dehydrated through an ethanol series: 10 min each in 30\%, 50\%, and 70\% EtOH. The brains were then transfered into $1 \%$ uranyl acetate in $70 \% \mathrm{EtOH}$ for $1 \mathrm{hr}$, then placed in $90 \%$ and $95 \% \mathrm{EtOH}$, followed by $3 \mathrm{x}$ 15-min washes in $100 \% \mathrm{EtOH}$. The brains were washed in propylene oxide (PO) 2 x 15 min, then moved through 3:1 PO:Epon/Araldite for $2 \mathrm{hrs,} \mathrm{1:1} \mathrm{PO:Epon/Araldite} \mathrm{overnight} \mathrm{on} \mathrm{a} \mathrm{rotator}$ at RT and fresh 100\% Epon/Araldite for $7 \mathrm{hrs,} \mathrm{and} \mathrm{finally} \mathrm{embedded} \mathrm{in} \mathrm{fresh} 100 \%$ Epon/Araldite. Corel Draw was used to assemble montages and to mask the images with a transparent overlay to show the position of the glial cells and their processes. Glial processes were identified by their characteristic inclusion of ribosomes and glycogen in the cytoplasm and, if the nucleus is present, by its irregular shape and infolding of the nuclear membrane. 


\section{Results}

Two major classes of glial cells invest the olfactory (antennal) nerve (AN). The centrally derived glial cells populate the region of the nerve most proximal to the antennal lobe, called the axonal sorting zone (Oland et al., 1998), while the peripherally derived (AN) glial cells migrate into the nerve from the olfactory sensory epithelium in the antenna, eventually forming a network of processes that surround bundles of olfactory receptor (ORN) axons. The entire nerve is ensheathed by perineurial cells and a sub-perineurial glial layer.

In the present study, we characterized in detail at the cellular level the development of the glial network. The first ORN axons reach the edge of the antennal lobe by late stage 3/stage 4 . Tracking the position of glial cell nuclei along the nerve showed in a previous study that AN glial cells migrate behind the ingrowing axons, the leading cells reaching the border of the sorting zone during stage 6 (Rössler et al., 1999). One experimentally useful consequence of the slightly delayed migration of AN glial cells into the very long antennal nerve is that, before stage 7, it's very easy to distinguish sorting zone and AN glial cells by position in both fixed preparations prepared for immunocytochemistry and in in situ preparations used for electrophysiology. The border between the two regions remains visually obvious under the dissecting microscope nearly to the end of the period of axon ingrowth.

\section{Development of the glial network in the antennal nerve}

Figure 1 shows schematically the developmental change in distribution of AN glial cells. The AN glial population in the nerve increases greatly during the period of migration, which begins 


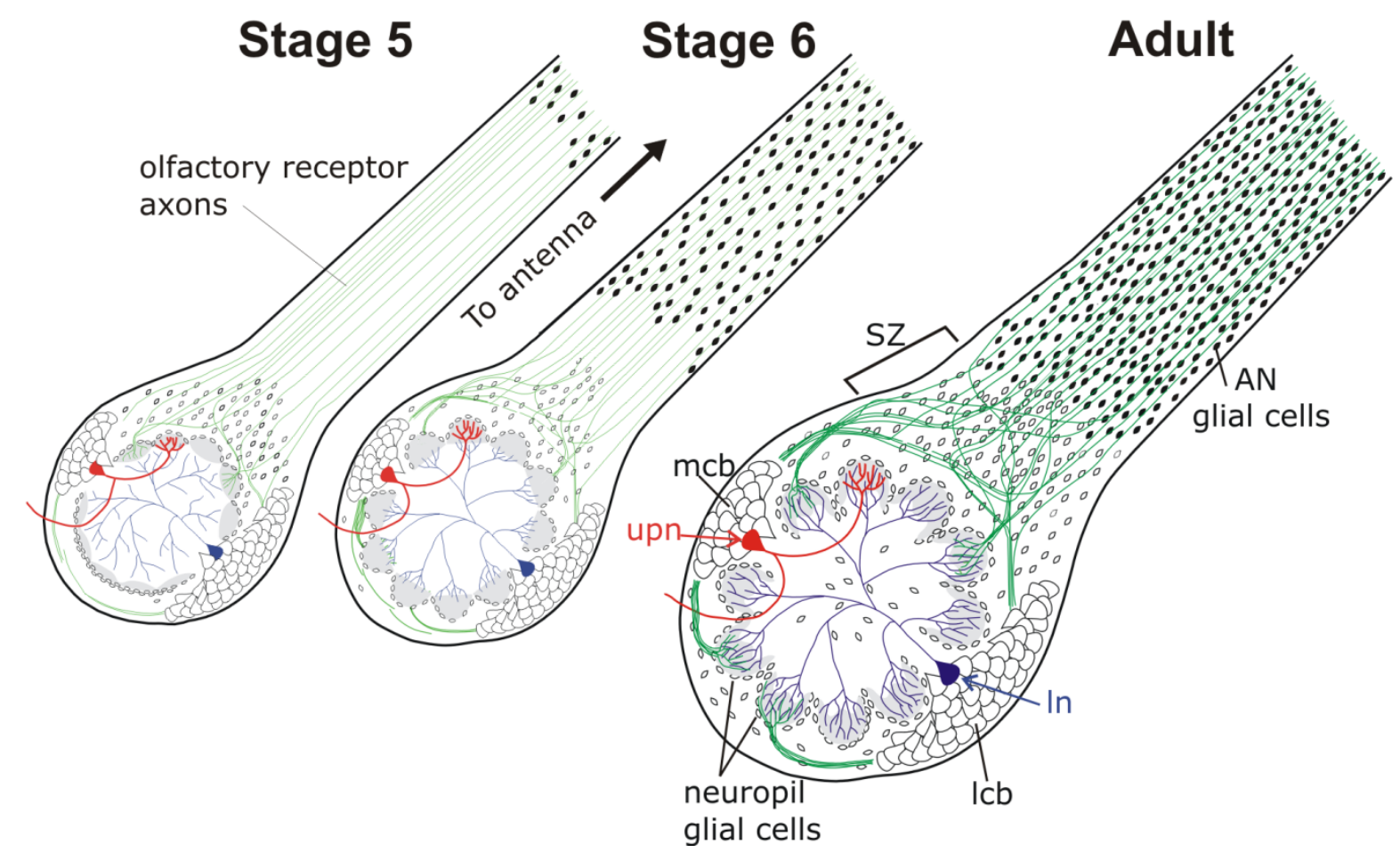

Fig. 1. Schematic diagrams of the moth olfactory pathway showing the position of the migrating peripheral (antennal nerve) glial cells at stages 5 and 6 and in the adult. AN, antennal nerve; Icb, lateral neuronal cell body cluster; In, local interneuron; mcb, medial neuronal cell body cluster; SZ, sorting zone; upn, uni-glomerular projection neuron.

as early as stage 3 (Rössler et al., 1999). Glial cells can be seen dividing in the antennal nerve branches in the antenna at this stage, the leading front of glial cells have migrated to the intracranial portion of the nerve by stage 5, and the first AN glia have reached the distal border of the sorting zone region of the nerve by the middle of stage 6. Phospho-histone H3 labeling of the intracranial portion of the nerve (Fig. 2 A,B) reveals an essentially constant level of division within the peripheral nerve glial population during the period of migration ( $\mathrm{n}=12$ preparations). The percent of cells dividing was $3.3 \%$ at stage $6,2.6 \%$ at stage 7 , and $3.3 \%$ at stage 9 , falling 

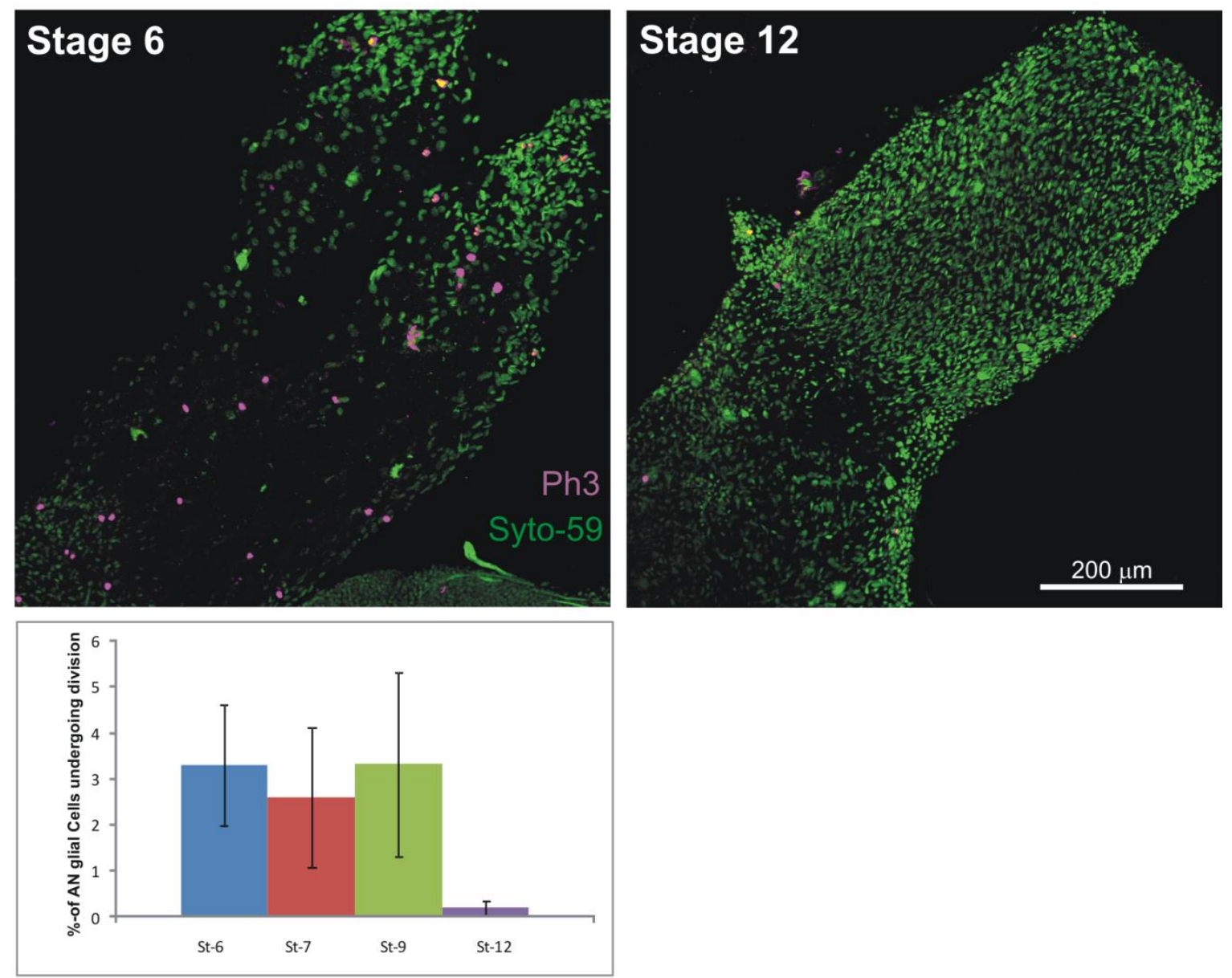

Fig. 2. Phospho-histone $\mathrm{H} 3$ labeling (magenta) shows that a small number of $A N$ glial cells (green) are dividing in the AN during the period of glial migration, which overlaps and extends slightly beyond the period of receptor axon ingrowth. The image from a stage- 6 nerve shows the nerve from near the antennal lobe (bottom left) to the base of the antenna (top right) where it divides into two antennal nerve branches. By stage 12, dividing glial cells were rarely detected in the AN. Bars in graph indicate $95 \%$ confidence intervals.

off drastically to $0.18 \%$ by stage 12 , a profile of division that closely matches the rising and then falling titer of the steroid hormone 20-hydroxyecdysone (Kirschenbaum et al., 1995). We do not know if the cells that were dividing were actively migrating, as has been reported to occur in NG2 glial cells of mice (Ge et al., 2009), or if they were simply paused, or had completed their migration. 
Labeling of the migrating AN glial cell population with anti-glutamine synthetase antibody shows that glial cells often appear in chains, as has been seen in other systems (Sepp et al., 2000; Gilmour et al., 2002; Silies et al., 2007; von Hilchen et al., 2008, Aigouy et al., 2008) (Fig. 3 AD). Glutamine sythetase labeling in the nerve disappears by the end of the migratory period, but interestingly, where it was limited to the AN glia during these early developmental times, it instead appears strongly in the central glia at stage 12 .
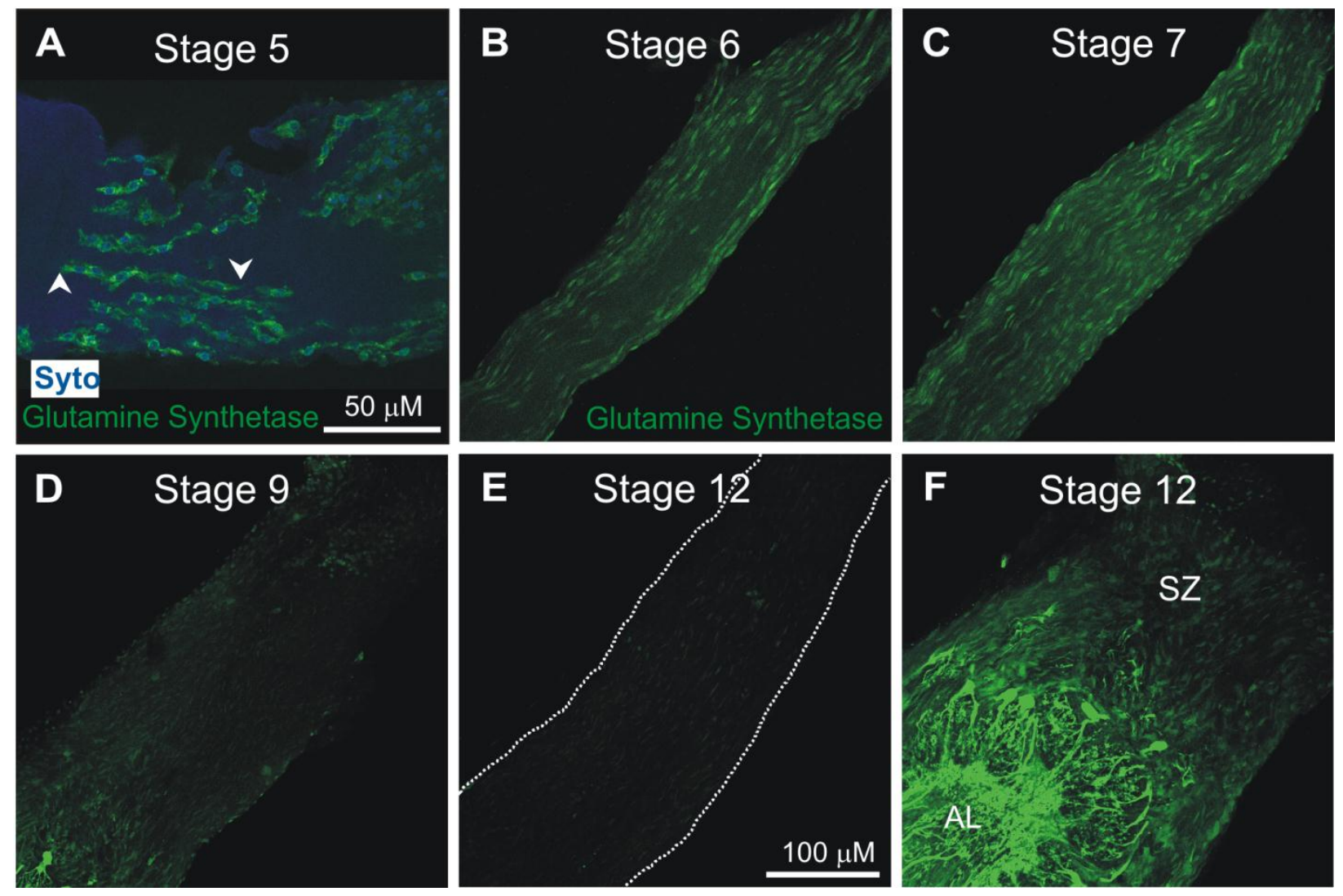

Fig. 3. Developmental changes in glutamine synthetase expression and distribution of migrating glial cells. A. Migrating glial cells often form chains of cells (e.g., between arrowheads). Glutamine synthetase labeling is present in AN glial cells early in their migration toward the antennal lobe (B), but gradually decreases in intensity until labeling is nearly absent by stage 12 (C-E). Dotted lines in E indicate edges of the nerve. F. Labeling in the central glial cells does not diminish. 
AN glial cells also are highly dye-coupled during the early stages of migration. During wholecell recording from these glial cells at different developmental stages, Lucifer Yellow was included in the recording electrode. Figure 4 shows that the dye spread to tens of cells across long distances at stage 6 , but coupling was dramatically reduced by one stage later. From stage 7 onward, dye from a single recorded glial cell never spread to more than 5 other glial cells,
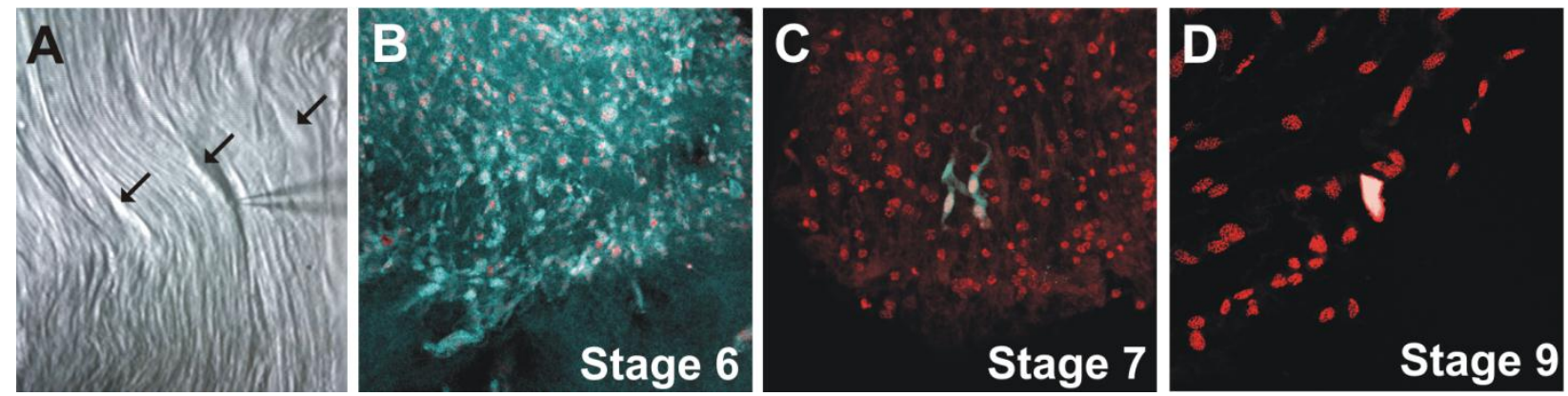

Fig. 4. Dye coupling in AN glial cells. A. Infra-red, water-immersion optics allows easy visualization of glial cell bodies (arrows) interspersed among the receptor axons. B. During stage 6, Lucifer Yellow diffuses from the single patched cell to tens of other glial cells across a wide portion of the nerve. C, D. At later stages, only small numbers of glial cells are dye-coupled.

indicating that coupling is developmentally regulated. We do not yet know if coupling is regulated by activity in the ORN axons in which spontaneous activity can first be detected in extracellular recordings from stage-7 nerves (Oland et al., 1996). We found no evidence of dye coupling between axons and glial cells.

The result of the migration, proliferation, and process extension is the formation of a network of glial processes. Figure 5A-C shows cross-sections through intracranial portion of the nerve at stages 6, 7 and 9. Glial processes in the sections were labeled with the lectin lycopersicon, which recognizes $N$-linked glycoproteins. The sequence shows the gradual increase in glial 

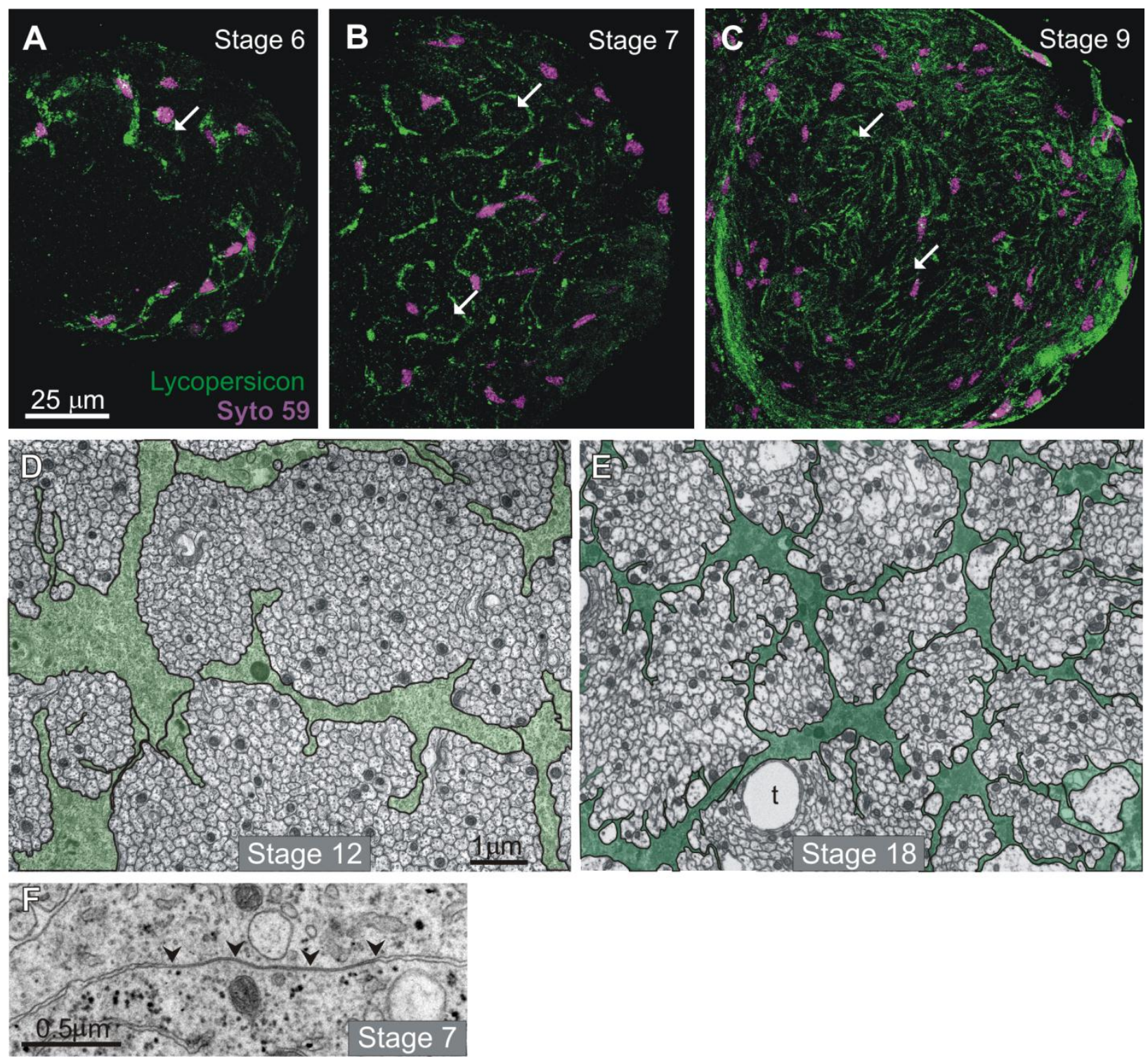

Fig. 5. Pattern of glial process extension in the development of the glial network in the antennal nerve. A-C. Glial processes, which begin as fairly thick processes, gradually become thinner and somewhat flattened, and branch to surround increasingly smaller roughly circular regions (arrows). D,E. At the electron microscopic level, comparison of cross-sections of stage-12 (D) and stage-18 (E) nerves reveals the processes to segregate smaller and smaller bundles of axons. Glial processes highlighted by transparent green overlay. F. Gap junctions between glial processes (arrowheads) are often found early in development, when dye-coupling between glial cells is extensive. Two circular profiles in top left corner are receptor axons. Scale bar in A applies to A-C; in D applies to D,E. 
investment of the nerve. During stages 6 and 7, glial cells have rather short processes and most glial cell nuclei are found closer to the outside of the nerve. In subsequent stages, the glial investment of the nerve develops as the glial cells migrate both along and into the body of the nerve and as the glial cells extend processes that branch and begin to roughly segregate groups of axons, seen as encircled regions of the nerve (arrows). The glial processes become more extensive and finer in caliber and vellate. At the EM level, comparison of images from crosssections of stage-12 (axon ingrowth complete) and stage-18 (just before emergence of the adult moth) nerves shows glial processes defining smaller and smaller subsets of axons (Fig. 5 D,E). As is the case for their vertebrate counterparts (Kreutzberg and Gross, 1977; Doucette, 1984; Barber and Lindsay, 1982), olfactory receptor axons in the moth are small-diameter $(0.1-0.2 \mu \mathrm{m})$ unmyelinated axons. In the mature nerve, these glial processes typically envelope groups of 5080 axons. The axons in these bundles are not yet sorted by odor-receptor subtype, but are merely traveling with axons whose origin is nearby in the sensory epithelium.

In higher magnification electron micrographs from cross-sections of the intracranial portion of the nerve at stage 7, extensive gap junctions could be found between glial cell processes (Fig. 5F), consistent with the finding that dye-coupling was seen at this stage, although only among small groups of glial cells. In micrographs from stage-18 nerves, gap junctions are difficult to find (not shown). We found no evidence of gap junctions between glia and axons at the EM level at any stage, consistent with findings in the vertebrate olfactory nerve (Blinder et al., 2005). 


\section{Glial cell electrophysiology during the period of axon ingrowth}

Whole-cell voltage-clamp recordings were taken at stages 6,7 , and 9 of metamorphic development. Recordings resulting from 100-msec or 1-sec step times with 10-mV voltage steps from a holding potential of $-70 \mathrm{mV}$, showed outward currents that activated at $-40 \mathrm{mV}$ and plateaued at an amplitude of approximately $500 \mathrm{pA}$ in about $150 \mathrm{msec}$ at all stages examined. Current-voltage plots show the similarities of the whole-cell family of currents throughout development and show no statistically significant difference in current amplitude among stages

(Fig. 6). The shape of the current profile varied, as seen in the responses to 1-sec voltage steps at different stages. These differences were not stage-specific, but could be seen at all stages from which we recorded. Differences could reflect migratory or cell-cycle status, or could reflect the presence of electrophysiologically distinct subsets of glial cells.

Current dissection. When the recording solution was replaced with 4-AP-containing recording solution, a reduction in the outward current was observed (Fig. 7B). The difference current displays inactivation, with a peak amplitude of $100 \mathrm{pA}$ occurring at $15 \mathrm{msec}$ (Fig. 7C); the remaining current had the appearance of a delayed-rectifier potassium current and was abolished in the presence of internal $\mathrm{Cs}^{+}$and an external 4-AP containing solution. Abolishing the outward current revealed an inward current of roughly 400-600 pA (Fig. 7D) that activated at $-50 \mathrm{mV}$ and could be abolished by application of $\mathrm{Cd}^{2+}$ or $\mathrm{Mg}^{2+}$. Because under standard whole-cell recording configuration the inward current decreased in amplitude rapidly over a period of 10 min and was completely lost within 30 minutes, we used Nystatin to achieve perforated-patch recordings (Fig.

8A). Because all currents could be abolished internal $\mathrm{Cs}^{+}$and external 4-AP and $\mathrm{Cd}^{2+}$ or $\mathrm{Mg}^{2+}$, we conclude that these glial cells exhibit only potassium and calcium currents. 
A

Short Pulse
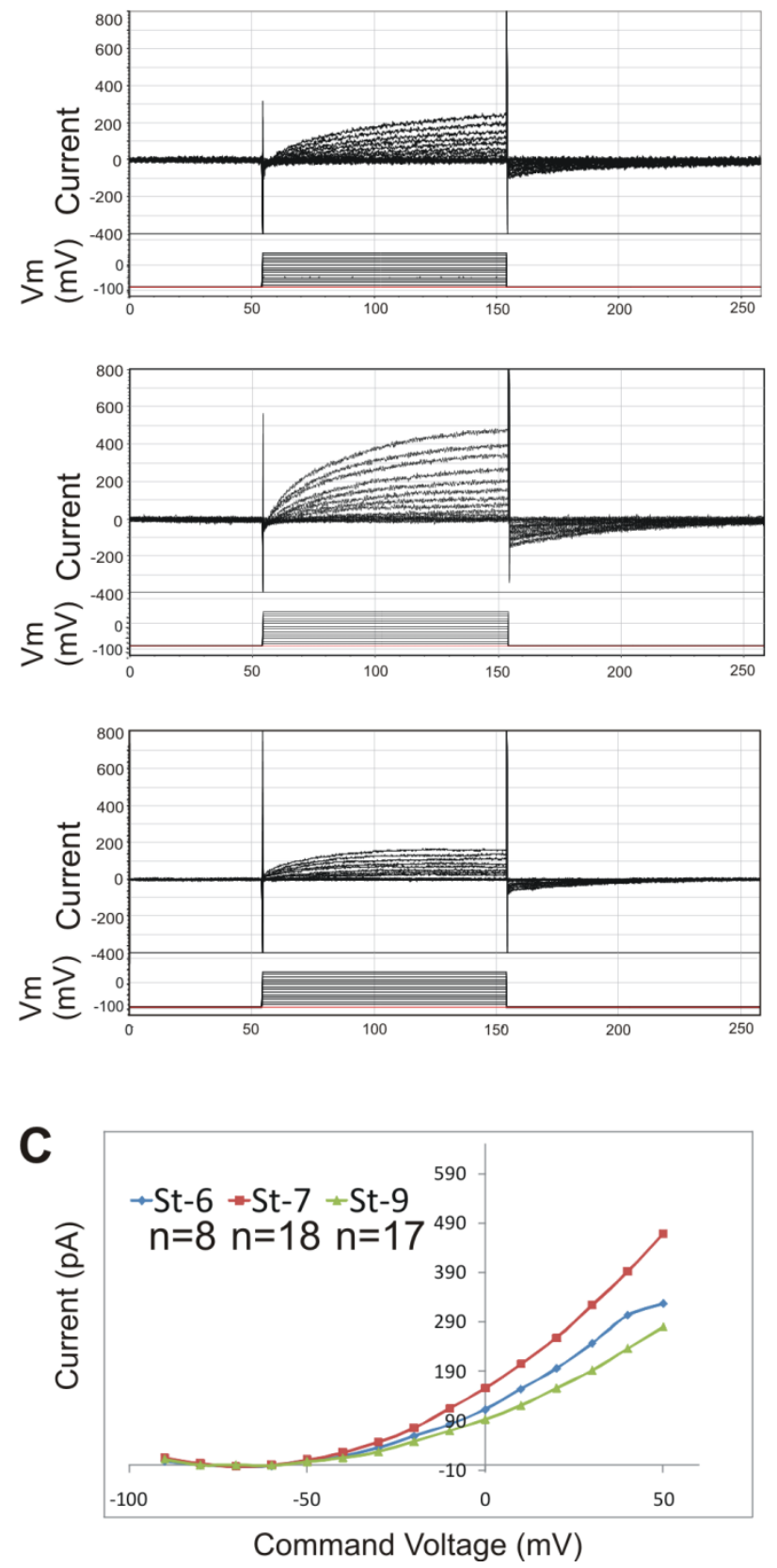

B Long Pulse
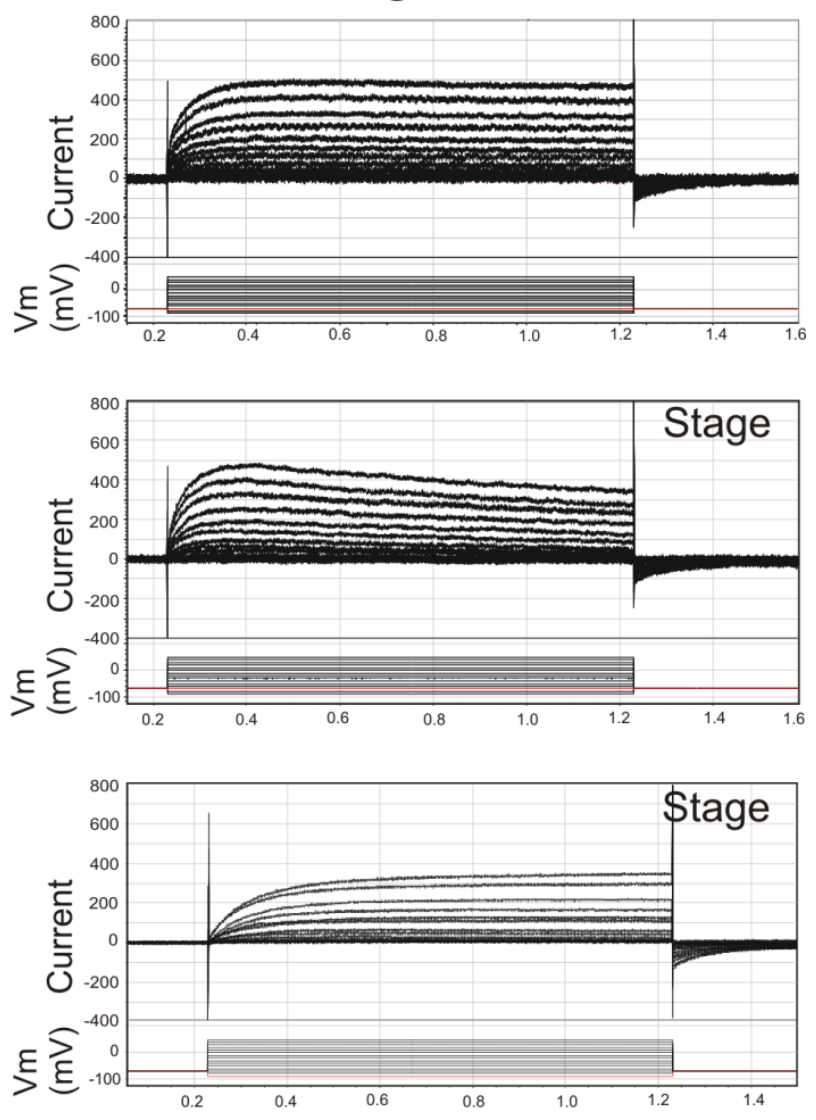

D

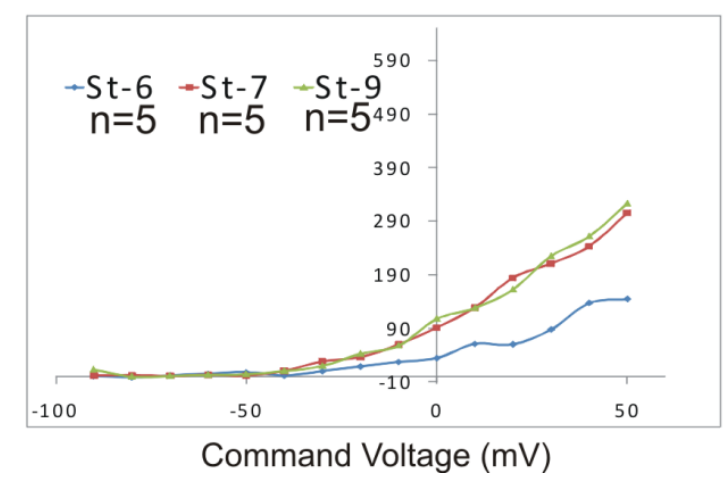

Fig. 6. Whole-cell currents in AN glial cells in situ at different stages of development in response to a family of $10 \mathrm{mV}$ voltage steps from a holding potential of $-70 \mathrm{mV}$. A. Short pulse $=100 \mathrm{msec}$. B. Long pulse $=1 \mathrm{sec}$. The shape of the current profile depicted for each stage could be seen at all stages. C,D. Corresponding I/V curves. Threshold of activation at $\sim-50 \mathrm{mV}$, is constant across stages. Bars show $95 \%$ confidence intervals and indicate no significant difference in amplitude across stages. 

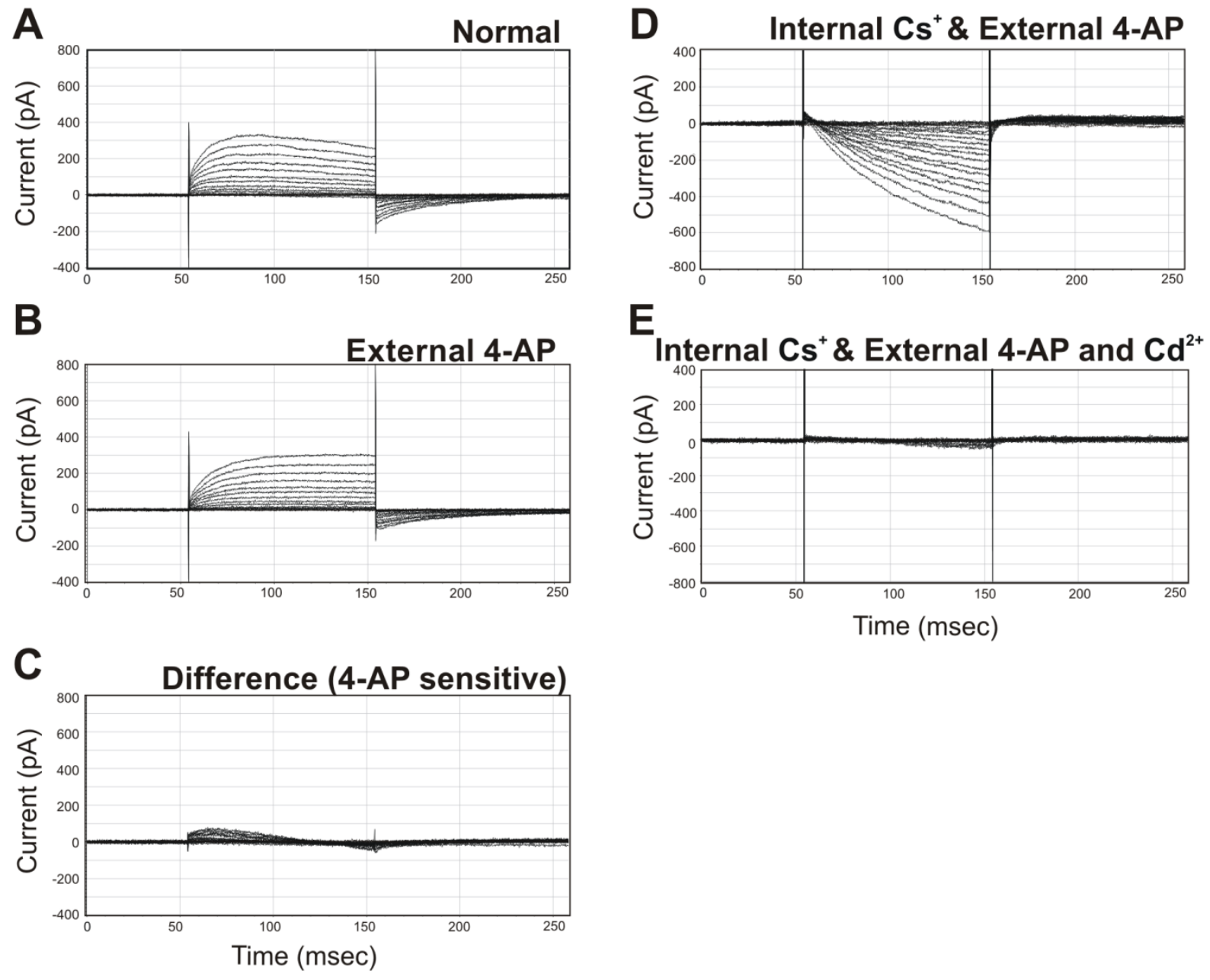

Fig. 7. AN glial cells in situ possess at least two types of outward potassium currents and an inward calcium current. All recorded at stage 7. A. Whole-cell current present in normal saline. B. External 4-AP blocks an A-like current (C) that peaks at $100 \mathrm{pA}$ and completely inactivates within $100 \mathrm{msec}$. D. Internal replacement of potassium with cesium in the presence of external 4-AP completely abolishes the outward current and unmasks an inward-going current that can be blocked with the addition of $\mathrm{Cd}^{2+}$ (E).

The L-type calcium-channel blocker, Verapamil, had been shown at high concentrations $(5 \mathrm{mM})$ to inhibit the migration of neuropil glial cells in $M$. sexta (Lohr, 2005). 5mM Verapamil was applied acutely and reduced the amplitude of the inward current by $\sim 2 / 3$ and washout reversed most of the reduction (not shown). Verapamil, however, can be rather poorly selective, especially at this concentration. The slow kinetics of the current suggested the possibility that 
the channel might be an R-like channel (Naidoo, 2010). R-like channels have been seen in neurons of Periplaneta americana (Benquet, 2004). The agatoxin SNX-482, a highly specific blocker of R-type channels (Naidoo, 2010), was pipetted into the recording chamber to yield a final concentration of $0.1 \mu \mathrm{M}$, and the response of the cell to a standard family of voltage steps was followed at 1-, 5- and 10-min intervals. The calcium current had already decreased at 1 minute, was abolished by 10 minutes, and could be recovered with a 10-min wash in recording solution even after repeated applications of SNX-482 (Fig. 8), leading to the conclusion that the inward current is an R-like current.

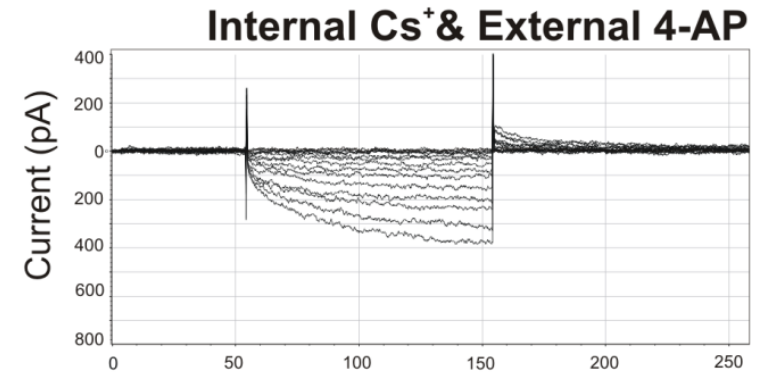

Internal $\mathrm{Cs}^{+}$\& External 4-AP
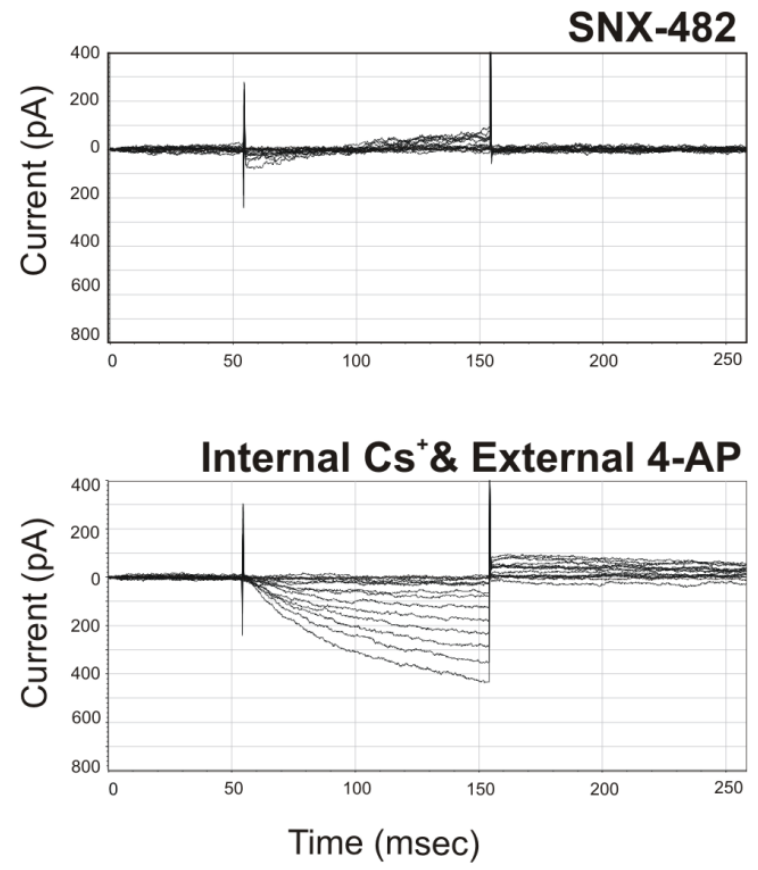

Fig. 8. The R-type channel blocker SNX-482 reversibly blocks the $\mathrm{Ca}^{2+}$ current recorded in AN glial cells in situ using perforated-patch technique. A. At stage 7, a slow-rising inward current in recorded in the presence of internal $\mathrm{Cs}^{+}$and external 4-AP. B. External application of the Rtype channel-blocker SNX-482 abolishes most of the inward current within 10 min, leaving only a small $(<50$ pA)early inward current and a small ( 75 pA) slow outward current.

$C$. The current is recovered with a 10min perfusion of saline with 4-AP. 


\section{Role of calcium currents and effect of blocking neuronal activity}

Because glial migration is a necessary part of the process of network formation in the antennal nerve and because the migration of the central glial cells has specifically been shown in the moth olfactory pathway to be calcium-dependent (Lohr et al., 2005), we examined the effect of blocking the R-like current on glial network formation.

Calcium blockers in vivo. We injected pupae with SNX-482 at early stage 5, when the first AN glial cells migrating from the antennal sensory epithelium are reaching the intracranial portion of the nerve, and repeated the injection daily to yield a total of 3 injections. Eighteen hours after the last injection, the animals had reached late stage 6 to early stage 7 of metamorphic development, with the SNX-482-injected animals lagging behind the water-injected control animals by less than 1 stage. The nerves were isolated and processed with syto-13 to monitor the extent of glial migration. The desheathed nerves of SNX-482 injected animals $(n=2)$ were visibly approximately the right diameter for the stages tested, but were devoid of AN glial cells as compared to the normally populated nerves of the vehicle-injected control animals $(n=2)$ (Fig. 9).

Interestingly, the centrally derived sorting zone glia that populate the base of the antennal nerve continued to migrate, while the centrally derived neuropil glial cells that form the glial envelopes around each glomerulus did not migrate as far into the neuropil as expected. We have not yet further characterized the migratory defect in the neuropil glial cells. 
Calcium blockers in vitro. It has been shown that AN glial cells, when co-cultured with ORN explants, form multi-cellular arrays over a period of 72 hours. In these arrays, glial cells form chains of a few to many cells, with the chains becoming increasingly interconnected with time. This array formation was shown to be independent of physical contact between the axons and glial cells but was dependent on both migration and proliferation of the glial cells (Tucker and Tolbert, 2003). Live-cell images were used to quantify chaining of AN glia in the vicinity of explants. Verapamil applied at concentrations up to $20 \mu \mathrm{M}$ (above which ORN explants and glial cells no longer appeared healthy) had no effect on the ability of the glial cells to form chains (not shown). A preliminary study with $\mathrm{SNX}-482$ at $0.1 \mu \mathrm{M}$, however, significantly reduced the percentage of glial cells involved in arrays (Fig. 9).

Effect of neuronal activity on glial calcium currents. When AN glial cells are exposed to TTX applied acutely during perforated-patch recordings, TTX had no effect on glial calcium currents (Fig. 10A,B). Thus, the glial cells themselves were insensitive to TTX and there was no effect of acutely reducing neuronal activity on the glial cell calcium current. In vivo, AN glial cells develop in the presence of ORN axons that display spontaneous neuronal activity. There is no evidence for calcium action potentials in the developing nerve (Zufall et al., 1991), and previous experiments showed that a single injection of TTX into metamorphosing animals chronically blocks neuronal activity. In cultured Manduca neurons, TTX blockade of sodium currents was irreversible (Hayashi and Levine, 1992), and when TTX was injected into pupae at stage3/early 4, the gin-trap motor reflex was abolished within 2-6 hrs and still could not be elicited 9-12 stages later. Also, in intracellular recordings made in TTX-treated animals during stages 12-16, no spontaneous action potentials could be recorded nor could action potentials be evoked by 

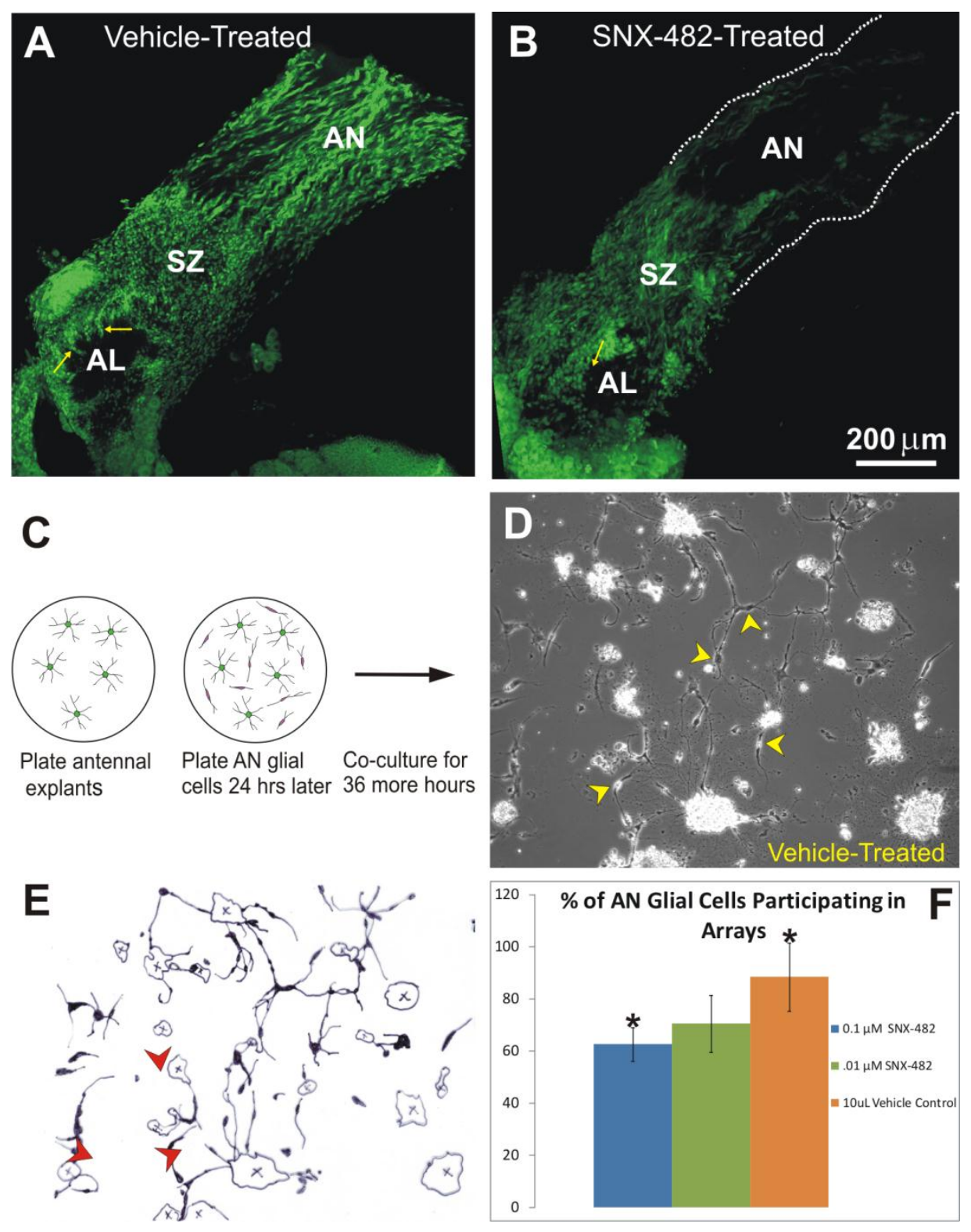

Fig. 9. Effect of blocking R-like $\mathrm{Ca}^{2+}$ current. A,B. Chronic exposure to SNX-482 in vivo by injection for 3 days beginning at stage 5 of metamorphic development stops AN glial migration, has no obvious effect on the migration of the centrally derived SZ glial cells, and reduces migration of the centrally derived neuropil glial cells (arrows). Dotted line in B indicates edges of the AN. C,D. In co-cultures of antennal explants, which contain olfactory receptor neurons, and AN glial cells, groups of glial cells near explants form multi-cellular arrays. Yellow arrowheads indicate cell bodies of AN glial cells. E. Example of tracing of glial cell arrays in vehicle-treated cultures. Arrows indicate glial cell nuclei. F. The percent of glial cells participating in arrays decreases significantly in the presence of $0.1 \mu \mathrm{M}$ SNX-482. Scale bar in B also applies to $A$. 
electrical stimulation of the antennal nerve, though both could be detected in vehicle-treated animals (Oland et al., 1996).
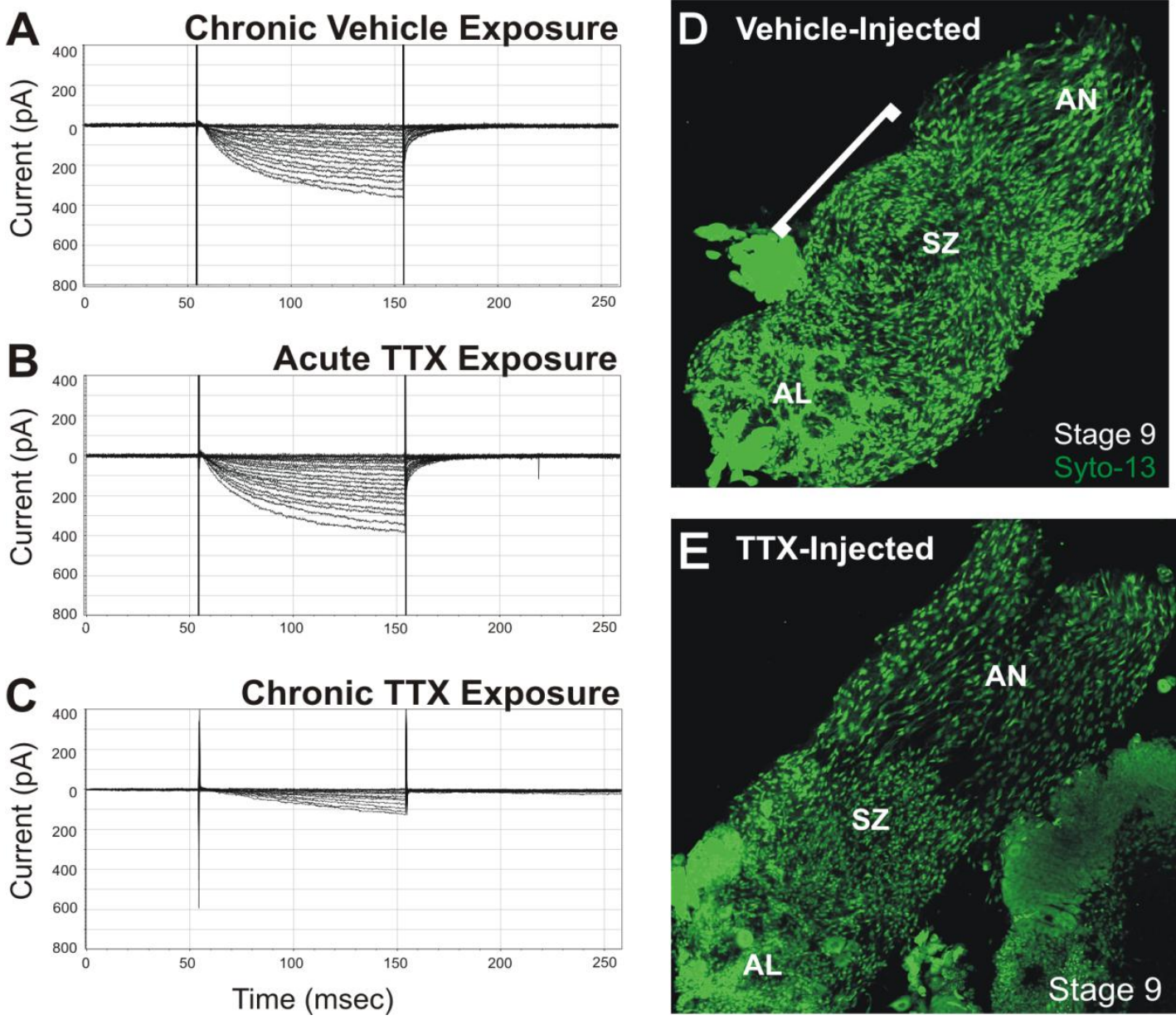

Fig. 10. Chronic inhibition of neuronal activity with TTX reduces the amplitude of the AN glial cell calcium current. Recordings from stage- 9 AN glial cells in situ using perforated-patch technique in the presence of external $\mathrm{Cs}^{+}$and internal 4-AP. A,B. Neither chronic exposure to vehicle by injection into the animal at stage 5 nor acute exposure to TTX during recording had any effect on the calcium current. $C$. C. After chronic exposure to $1 \mu \mathrm{M}$ TTX by injection at stage 6 , the $\mathrm{Ca}^{2+}$ current recorded in situ was severely reduced. D,E. There was no visibly obvious effect on AN glial migration after chronically blocking neuronal activity with TTX. 
Thus we were able to test whether the development of calcium currents in AN glial cells is dependent on neuronal activity by exposing animals to $1 \mu \mathrm{M}$ TTX by injection at stage 6 , just prior to time when spontaneous activity first can be detected in ORN axons (Oland et al., 1996). We recorded from AN glial cells in stage-9 TTX-treated or vehicle-treated control animals using a perforated-patch configuration (Fig. 10). The amplitude of the calcium current in the TTXtreated AN glial cells was consistently reduced to $\sim 150 \mathrm{pA}(\mathrm{n}=7$ of 8 ); the amplitude of the current in the vehicle controls was $\sim 450 \mathrm{pA}(\mathrm{n}=4)$. We do not know if there is a sensitive period during which development of the glial calcium current is dependent on neuronal activity.

We also examined the extent of glial cell migration in TTX-treated antennal nerves. There were no obvious changes in glial density or position (Fig. 10). Thus, neuronal activity does influence the development of calcium currents in AN glial cells, but does not affect the ability of AN glial cells to migrate.

\section{Discussion}

We found that AN glial cells migrate along the nerve to form a glial network that surrounds small bundles of ORN axons. During the period of migration, glial cells along the nerve divide and are initially highly dye-coupled. In the developing nerve, they exhibit at least 2 potassium currents and a calcium current, and the calcium current is reduced when neuronal activity in the nerve is blocked. Something about network array in vitro if SNX works. Our data suggest that an interaction between AN glial cells and the ORN axons underlies development of the glial calcium current and that the calcium current in turn is required for development of the normal architecture of the nerve. 


\section{Network formation}

At the cellular level, formation of the glial network in the moth antennal nerve comprises several steps: gliogenesis, migration from the sensory epithelium (Rössler et al., 1999), and process extension to ensheathe axonal bundles. Glial proliferation begins in the sensory epithelium as early as stage 3 (Rössler et al., 1999), shortly after the birth of the olfactory receptor neurons (Sanes and Hildebrand, 1976). In the moth, which has a substantive nerve comprising more than 300,000 axons (Sanes and Hildebrand, 1975; Oland and Tolbert, 1989), dividing glial cells also are found throughout the nerve as the population is migrating toward the brain. We do not know if glial cells are proliferating while migrating, as has been shown in NG2 glial cells of mice (Ge et al., 2009), or if the only proliferating glial cells are those that have reached their terminal position in the nerve. Nor do we know in Manduca to what signals glial cells are responding that determine their terminal position or their spacing from each other. Reduction in FGFR activation has been implicated in halting the migration of glial cells into the Drosophila eye imaginal disc (Silies et al., 2007; Murakami et al., 2007), but elsewhere this part of the process simply is poorly understood, even in systems where good progress has been made in identifying key signaling pathways that initiate and maintain glial migration (Klambt, 2009).

Collective or chain migration is a fundamental feature of migration in Drosophila wing and peripheral nerve (Giangrande, 1994; Sepp et al., 2000; Aigouy et al., 2004; von Hilchen et al., 2008), in the Manduca enteric nervous system (Copenhaver and Taghert, 1989; Wright and Copenhaver, 2000) and in zebrafish peripheral nerves (Kucenas et al., 2008). In the moth antennal nerve, AN glial cells often appear in chains in vivo especially at the early stages of 
migration although the dimensions of the nerve and the pattern of glial process extension indicate that chaining along cannot be responsible for continuous ensheathment of axon bundles. A more complex behavior in the moth olfactory system is also suggested by the formation of multicellular glial arrays in vitro when the glial cells are grown close to but not necessarily in contact with receptor axons (Tucker and Tolbert, 2003). In these experiments, the formation of the multi-cellular arrays was the result of proliferation, glial cell migration and process extension in response to an as yet unidentified short-range diffusible signal. The current in vivo TTX data also support this finding since the glial processes investing the developing nerve do not associate individually with each axon.

During the early migratory phase in Manduca, at least as early as we have recorded from them, AN glial cells are highly dye coupled, raising the possibility that some of the signals affecting the migratory or proliferation pattern of the glial cells may be passed via gap junctions among the AN glial cells. In other systems in which glial cells migrate in chains (LeCaudey and Gilmour, 2006), the leading glial cells must pass to the follower cohort information that maintains the chain of glial cells. Whether gap junctions between the cells forming a chain participate in coordinating the pioneer and follower cells is not yet known. Alternatively, signals that coordinate migration and proliferation within a group of glial cells may be disrupted by the loss of gap junctional coupling, allowing the cells to stop migrating and to develop their mature morphological and physiological state (Caveney, 1985).

What causes the dramatic loss of dye coupling among moth glial cells between stages 6 and 9 ? The reduction in dye-coupling may be due largely to loss of gap junctions as gap junctions were 
easy to find in high magnification electron micrographs at stage-7, but difficult to detect thereafter. Also at the time the coupling is reduced, the titer of the steroid hormone 20hydroxecdysone is near its peak (Kirschenbaum et al., 1995) and receptor axons in the nerve have detectable spontaneous electrical activity (Oland et al., 1996). In contrast, in mice, gap junctions are readily detected between olfactory ensheathing cells (OECs) the adult by both immunocytochemistry and electrophysiology in the olfactory nerve layer, though OECs varied in the number of OECs to which they were coupled via gap junctions (Rela et al., 2010). Whether small, difficult to discern junctions remain between glial processes at more mature stages in the moth, and if so, whether the coupling ratio among them is regulated (Stebbings et al., 2002) and whether there are functional glial domains comprising small numbers of glial cells within the mature nerve remains to be determined.

In other systems, such as the Drosophila embryo, long-distance signals such as Netrin guide the migration of the longitudinal glial cells (von Hilchen et al., 2010). In the moth, however, a longdistance signal from the target that regulates the directionality of glial migration is unlikely. The brain can be removed at the start of metamorphic development and a nerve still forms, though ended by a neuroma, and glial cells migrate into the nerve (Oland et al., 1998). Receptor axons, on the other hand, are attracted to the antennal lobe by a diffusible signal (Oland et al., 2003).

The third stage of network formation is process extension. The axonal bundles coursing along the mature antennal nerve are ensheathed by the processes of the peripherally derived AN glial cells, though we do not know to how many bundles a single glial cell might contribute. The glia enwrap bundles of 50-80 small-diameter axons, giving the antennal nerve a cross-sectional 
appearance similar to that of the olfactory nerve in vertebrates (Kreutzberg and Gross, 1977; Doucette, 1984; Barber and Lindsay, 1982; Burd, 1991). This pattern of glial ensheathment of bundles of small-diameter axons is also seen in the vertebrate central nervous system, for example in the cerebellar array of parallel fibers (Peters et al., 1991) and in Lissauer's tract in the spinal cord (Chung and Coggeshall, 1977). But in Drosophila, the functionally equivalent glial cells that enwrap the axonal bundles in the antennal (olfactory) nerve are centrally derived (Sen et al., 2005); glial cells that arise in the olfactory sensory epithelium of the antenna form a sheath around the nerve branches in the antenna and contribute to the network of glial processes associated with the cell bodies of the sensory neurons (Jhaveri et al., 2000).

The pattern of ensheathment in olfactory nerves is very different from that seen in most peripheral nerves. In vertebrates, non-myelinating Schwann cells extend processes around small-diameter axons, separating each individual member of the axonal group from its neighbor in a structure called a Remak bundle. Remak-like bundles also are formed by wrapping glia in the typical peripheral nerve of Drosophila as well as by Schwann cells in immature vertebrate peripheral nerves (Rodrigues et al., 2011).

The functional consequence of ensheathing bundles of small axons rather than providing a glial wrap for individual axons is unknown, but is especially interesting in the context of the olfactory nerve where the axons in each bundle are not expected to share an odotypic phenotype and therefore would not be expected to be simultaneously active in response to stimulation with a particular odorant. The question arises then, what is the physiological function of this arrangement? Because the axons in a bundle are not related by a shared olfactory receptor in the 
antennal nerve of the moth or in the olfactory nerve of vertebrates, having not yet reached the sorting regions of the pathway, the role cannot be one of electrical isolation of groups of related active axons. The glia could be serving the traditional role of metabolic support (Nave and Trapp, 2008), the consistency in the size of the bundles in both vertebrate and invertebrate olfactory nerves suggesting that there might be an optimal distance from active axons at which a glial cell presence is required. On the other hand, though Xenopus axon bundles in the olfactory nerve are typically in the same range, bundles as large as several thousand axons are present in the nerve (Burd, 1991), suggesting that a simple distance argument does not explain the arrangement. In other olfactory systems, OECs have been shown to support axon extension (Kafitz and Greer, 1999) in culture and in vivo (Li et al., 2005), and several studies have implicated OECs as a source of neurotrophic factors (Mackay-Sim and Chuah, 2000; Carter and Roskams, 2002; Su and He, 2010). The former is useful in a system in which there is continuous axon ingrowth in the adult, but may be important in the later stages of axon ingrowth during development in the moth; the latter is reasonable in both systems.

\section{Calcium current in the AN glial cells}

Calcium transients in glial cells have been reported many systems, including olfactory ensheathing cells in the mammalian olfactory bulb (Reiger et al., 2007), astrocytes in the cortex (van den Pol et al., 1992), and neuropil glial cells in the olfactory (antennal) lobe of the moth and in the giant glial cells of medicinal leech ganglia (Lohr et al., 2005; Lohr and Deitmer, 2006). Many of these calcium transients in invertebrates have been attributed to voltage-gated calcium 
channels (Lohr and Dietmer, 2006), but we have found no reports of recordings from glial cells in invertebrate nervous systems in which the type of calcium current was identified.

In the current study, abolition of the dominant outward potassium currents with $\mathrm{Cs}^{+}$and 4-AP revealed a voltage-gated inward current that could be abolished with external $\mathrm{Cd}^{2+}$, or $\mathrm{Mg}^{2+}$ indicating it is a calcium current. Exposure to SNX-428 further characterized the current as an R-like current (see below). There is no evidence for $\mathrm{Na}^{+}$channels in the $\mathrm{AN}$ glia, including lack of response to TTX, though expression of $\mathrm{Na}^{+}$channels has been described in mammalian astrocytes (e.g. Waxman and Black, 1995).

We initially found that the calcium current was reduced by verapamil (not shown), an L-type channel blocker, but only at concentrations at which verapamil has been shown to be nonselective (Diochot et al., 1995). The kinetics of the currents we recorded could not be used to classify the type of calcium current in part because, although we showed that dye coupling was dramatically reduced between stages 6 and 7, we do not know whether coupling can be modulated by neuronal activity during the stages from which we recorded. Nevertheless, the relatively slow rise time suggested the possibility that the current could be an R-like current. (Shih et al., 2010). R-like currents mostly have been described in vertebrate neurons where in rat they have been shown to be involved in the formation of presynaptic calcium microdomains that evoke long term potentiation at parallel fiber-to-Purkinje cell synapses (Myoga and Regehr, 2011). They also have been reported in cultured cockroach embryonic neurons where they showed a developmentally regulated increase in current density (Benquet et al., 2004) and were associated with both survival and neurite outgrowth (Benquet et al., 1999). In the moth AN glia, 
the inward current can be almost completely abolished, reversibly, by exposure to 100 nM SNX482, indicating that these glial cells express a voltage-gated R-like calcium channel.

Developmentally, glial migration in the AN has begun as early as stage 3 of metamorphic development, a stage at which NP glia have not yet developed calcium transients (Lohr et al., 2002). In the latter, calcium transients begin to appear at stage 6 , and are present in all NP glial cells by stage 7; stage 6 is the stage at which NP glial cells begin to migrate to surround and stabilize developing glomeruli (Lohr et al., 2005; Lohr and Deitmer, 2006; Bauman et al., 1996). Our whole-cell recordings from AN glial cells at stage 6, when the AN glia first reach the intracranial portion of the nerve, show the calcium current to be present in at least a subset of AN glia at stage 6 and in all glial cells by stage 7, similar to the finding in the NP glia. Because the AN glia have begun to migrate at stage 3, however, we would predict that we would find a calcium current in AN glial cells at the time they first enter the AN rootlets in the antenna.

In vivo exposure to SNX-482 during the first three days of glial migration into the nerve resulted in a lack of glial investment in the nerve, and our preliminary in vitro data indicate that the percent of glial cells involved in array formation also was decreased (an effect on either migration or proliferation). We know that blocking $\mathrm{Na}^{+}$-based activity in ORNs with chronic TTX exposure did not block AN glial migration, and Zufall et al. (1991) reported that Manduca ORNs lack a voltage-gated calcium channel. Taken together, these data indicate that the inhibition of glial migration seen with SNX-exposure was due to blocking an R-like glial calcium current in the AN glial cells. Reduction of the calcium current, by chronic exposure to TTX or by verapamil (not shown), was not, however, sufficient to block migration, implying that 
migration of AN glial cells can occur within a fairly wide range of cytosolic calcium concentrations.

We do not yet know whether the effect of blocking the R-like current only affected migration of the glial cells or also affected their proliferation. It also is interesting that the migration of one subset of centrally derived glial cells, the SZ glia, was not affected while the other subset, the neuropil glial cells, was. These differences could imply either a temporal difference in sensitivity to the drug, a difference among the cell types in the molecular pathways underlying migration, or a context-dependent difference among the cell types in regulation of those pathways.

The disruption of migration of AN glial cells caused by blocking the R-like current in the moth olfactory nerve provides an opportunity to explore the functional role of this sort of glial/axonal arrangement. At the gross anatomical level, the perineurial and subperineurial layers appear to be intact, reducing the possibility of osmotic, toxic or inflammatory effects due to disruption of the blood-brain barrier. Previous studies in which Drosophila glial cells are genetically removed or ablated from peripheral nerves are somewhat difficult to interpret because the barrier may also be affected. For example, in glial cells missing, axons in the peripheral nerves are disorganized structurally, with regions of degeneration and swelling of the extracellular space (Banerjee et al., 2006). In fray mutants, ensheathment is abnormal in larval peripheral nerves and axons often are swollen in regions along the nerve (Leiserson et al., 2000), but recent studies in the mammalian homologue of fray have revealed that the mutation affects transporter activity that may be important in maintaining normal ionic homoeostasis, a function separate from the ensheathing function (Piechotta et al., 2002). 


\section{Role of activity in network formation}

The ensheathment of small bundles is essentially complete at about the time the animal becomes responsive to odorants, during the last few stages of metamorphic adult development (Schweitzer

et al., 1976), but begins during earlier stages when spontaneous action potentials first appear in the receptor axons. Glia are known to respond to neuronal activity. For example, astrocytes display activity-dependent changes in cytosolic calcium (Chiu et al. 1994), mouse olfactory ensheathing cells show calcium transients in response to the glutamate and ATP released by electrical stimulation of the olfactory nerve (Reiger et al., 2007), Schwann cells in peripheral nerves respond to ATP released from active axons (Grafe et al., 2006), and ATP released from dorsal root ganglion cells elicits calcium transients in immature Schwann cell that in turn inhibit Schwann cell proliferation and differentiation (Stevens and Fields, 2000).

Other mechanisms that could elicit responses in glial cells in response to neuronal activity include vesicular release of transmitter, in this case acetylcholine (Stengl et al., 1990), as has been shown in developing Xenopus spinal cord neurons (Antonov et al., 1999; Zakharenko et al., 1999) and in developing hippocampal neurons (Gao and Van den Pol, 2000). Lohr et al. (2005) showed that calcium transients in neuropil glial cells in the moth developed shortly after the arrival of olfactory receptor axons and failed to appear in systems chronically deprived of receptor axons. What was not clear, however, was whether the absence of calcium transients was due specifically to activity in the receptor axons, or even to spontaneous release of transmitter from the tips of growing axons (Young and Poo 1983). In the current study, the reduction in the R-like current was induced by loss of neuronal activity. Given the importance of 
calcium in numerous developmental processes, this particular neuron-glial cell interaction may have widespread effects, beyond possible regulation of coupling or glial cell migration. Whether in this system AN glia calcium currents remain sensitive to neuronal activity into adulthood is not yet known, but it would not be surprising if the AN glial cells remained dynamically in tune with the activity of the neurons they enwrap.

\section{Summary}

AN glial cells migrate along the antennal nerve to form a glial network that surrounds small bundles of olfactory receptor axons. During the period of migration, glial cells along the nerve divide and are initially highly dye-coupled. In the developing nerve, they exhibit at least 2 potassium currents and an R-like calcium current, and the calcium current is reduced when neuronal activity in the nerve is blocked. Interaction between AN glial cells and the receptor axons underlies development of the glial calcium current and that the calcium current in turn is required for development of the normal architecture of the nerve. 


\section{Acknowledgements}

The authors gratefully acknowledge the help of Margaret Marez, who maintains the Manduca colony; Anna Burns, who manages the Cell Culture Facility and made solutions and culture dishes; Patricia Jansma, who manages the Imaging Facility and provided excellent technical advice on immunocytochemisty and microscopy; Nicholas Gibson, who generously provided us with the images that appear in Figure 5A-C; Jinhui Zhang, who generously provided us with the image that appears in Figure 5F; and Jon Hayashi, who was an essential guide in MK's early training in whole-cell methods. Funding for this project was provided by NIH NIDCD DC00857 to LAO, HHMI 52003749 in support of MK through the University of Arizona Undergraduate Biology Research Program, and a Microscopy Society of America Undergraduate Research Award to MK. 


\section{References}

Aigouy B, Van de Bor V, Boeglin M, Giangrande A (2004) Time-lapse and cell ablation reveal the role of cell interactions in fly glial migration and proliferation. Development 131:5127-5138.

Aigouy B, Lepelletier L, Giangrande A (2008) Glial chain migration requires pioneer cells. J Neurosci. 28:11635-41.

Antonov I, Chang S, Zakharenko S, Popov SV.(1999) Distribution of neurotransmitter secretion in growing axons. Neuroscience. 90:975-84.

Au WW, Treloar HB, Greer CA (2002) Sublaminar organization of the mouse olfactory bulb nerve layer. J Comp Neurol 446:68-80.

Bailey MS, Shipley MT (1993) Astrocyte subtypes in the rat olfactory bulb: morphological heterogeneity and differential laminar distribution. J Comp Neurol 328:501-26.

Banerjee S, Bhat MA (2007) Glial ensheathment of peripheral axons in Drosophila. J Neurosci Res 86:1189-1198.

Banerjee S, Pillai Am, Paik R, Li J, Bhat MA (2006) Axonal ensheathment and septate junction formation in the peripheral nervous system of Drosophila. J Neurosci 26;3319-3329.

Barber PC, Lindsay RM (1982) Schwann cells of the olfactory nerve contain glial fibrillary acidic protein and resemble astrocytes. Neuroscience 7:3077-3090.

Baumann PM, Oland LA, Tolbert LP. (1996). Glial cells stabilize axonal protoglomeruli in the developing olfactory lobe of the moth Manduca sexta. J Comp Neurol 373:118-28.

Benquet P, Pichon Y, Tiaho F (2004) in vitro development of P- and R-like ccalcium currents in insect (Periplaneta americana) embryonic brain neurons. Neurosci Lett 365:228-232.

Benquet P, Guen JL, Dayanithi G, Pichon Y, Tiaho F (1999) Omega-AgaIVA-sensitive (P/Qtype) and -resistant (R-type) high-voltage-activated $\mathrm{Ba}(2+)$ currents in embryonic cockroach brain neurons. J Neurophysiol 82:2284-93.

Benquet P, Pichon Y, Tiaho F (2004) In vitro development of P-and R-like calcium currents in insect (Periplaneta americana) embryonic brain neurons. Neurosci Lett. 365:228-32.

Blinder KJ, Pumplin DW, Paul DL, Keller A (2003) Intercellular interactions in the mammalian olfactory nerve. J Comp Neurol 466:230-239.

Burd GD (1991) Development of the olfactory nerve in the African clawed frog, Xenopus laevis: I. Normal development. J Comp Neurol 304:123-134. 
Carter LA, Roskams AJ (2002) Neurotrophins and their receptors in the primary olfactory neuroaxis. Microsc Res Techniq 58:189-196.

Caveney S (1985) The role of gap junctions in development. Annu Rev Physiol 47:319-35.

Chiu SY, Kriegler S (1994) Neurotransmitter-mediated signaling between axons and glial cells. Glia 11 (2): 191-200.

Chung K, Coggeshall RE (1979) Primary afferent axons in the Tract of Lissauer in the cat. J Comp Neurol 186: 451-464.

Copenhaver PF, Taghert PH (1989) Development of the enteric nervous system in the moth. II. Stereotyped cell migration precedes the differentiation of embryonic neurons. Dev Biol 131:85101.

DeLorenzo AJ (1957) Electron microscopic observations of the olfactory mucosa and olfactory nerve. J Biophys Biochem Cytol 3:839-850.

Diochot S, Richard S, Baldy-Mounlinier M, Nargeot J, and Valmier (1995) Dihydropyridines, phenylalkylamines and benzothiazepines block N-, P/Q- and R-type calcium currents. Pflugers Arch. 431(1):10-19.

Doucette JR (1984) The glial cells in the nerve fiber layer of the rat olfactory bulb. Anat Rec 210:385-391.

Gao XB, van den Pol AN. 2000. GABA release from mouse axonal growth cones. J Physiol 523: 629-637.

Ge WP, Zhou W, Luo Q, Jan LY, Jan YN (2009) Dividing glial cells maintain differentiated properties including complex morphology and functional synapses. Proc Natl Acad Sci U S A. 106:328-33.

Giangrande, A (1994) Glia in the flywing are clonally related to epithelial cells and use the nerve as a pathway for migration. Development 120: 523-534.

Gilmour DT, Maischen HM, Nüsslein-Volhard C (2002) Migration and function of a glial subtype in the vertebrae peripheral nervous system. Neuron 34:577-588.

Grafe P, Schaffer V, Rucker F (2006) Kinetics of ATP release following compression injury of a peripheral nerve trunk. Purinergic Signal 2(3):527-36.

Hayashi JH, Levine RB (1992) Calcium and potassium currents in leg motoneurons during postembryonic development in the hawkmoth Manduca sexta. J Exp Biol. Oct;171:15-42.

Jhaveri D, Sen A, Rodrigues V. 2000. Mechanisms underlying olfactory neuronal connectivity in Drosophila - the atonal lineage organizes the periphery while sensory neurons and glia pattern the olfactory lobe. Dev Biol 226:73-87. 
Kafitz KW, Greer CA (1999) Olfactory ensheathing cells promote neurite extension from embryonic olfactory receptor cell in vitro. Glia 25:99-110.

Kirschenbaum SR, Higgins MR, Tveten M, Tolbert LP (1995) 20-Hydroxyecdysone stimulates proliferation of glial cells in the developing brain of the moth Manduca sexta.

J Neurobiol 28:234-247

Klämbt C (2009) Modes and regulation of glial migration in vertebrates and invertebrates. Nature Rev 10:769-779.

Koizumi S (2010) Synchronization of $\mathrm{Ca} 2+$ oscillations: involvement of ATP release in astrocytes. FEBS J 277:286-92.

Kreutzberg GW, Gorss GW (1977) General morphology and axonal ultrastructure of the olfactory nerve of the pike, Esox lucius. Cell Tiss Res 181:443-457.

Kucenas S, Takada N, Park HC, Woodruff E, Broadie K, Appel B (2008). CNS-derived glia ensheath peripheral nerves and mediate motor root development. Nat Neurosci. 11:143-51.

Lecaudey V \& Gilmour D (2006) Organizing moving groups during morphogenesis. Curr. Opin Cell Bio 18:102-107.

Li Y, Li D, Raisman G (2005) Interaction of olfactory ensheathing cells with astrocytes may be the key to repair of tract injuries in the spinal cord: the "pathway hypothesis.' J Neurocytol 34:343-351.

Lieserson WM, Harkins EW, Keshishian H (2000) Fray, a Drosophila serine/threonine kinase homologous to mammalian PASK, is required for axonal ensheathment. Neuron 28:793-806.

Lohr C, Deitmer JW (2006) Calcium signaling in invertebrate glial cells. Glia. 54:642-9.

Lohr C, Heil JE, Deitmer JW (2005) Blockage of voltage-gated calcium signaling impairs migration of glial cells in vivo. Glia 50:198-211.

Lohr C, Tucker E, Oland LA, Tolbert LP (2002) Development of depolarization-induced calcium transients in insect glial cells is dependent on the presence of afferent axons. J Neurobiol 52:8598.

Mackay-Sim A, Chuah MI (2000) Neurotrophic factors in the primary olfactory pathway. Prog Neurobiol 62:527-559.

Morton DB, Truman JW (1985) Steroid regulation of the peptide-mediated increase in cyclic GMP in the nervous system of the hawkmoth, Manduca sexta. J Comp Physiol A 157: 423-432. 
Munsch T, Deitmer JW (1992) Calcium transients in identified leech glial cells in situ evoked by high potassium concentrations and 5-hydroxytryptamine. J Exp Biol 167:251-265.

Murakami S, Umetsu D, Maeyama Y, Sato M, Yoshida S, Tabata T. (2007) Focal adhesion kinase controls morphogenesis of the Drosophila optic stalk. Development. 134:1539-48.

Myoga MH, Regehr WG (2011) Calcium microdomains near R-Type calcium channels control the induction of presynaptic long-term potentiation at parallel fiber to purkinje cell synapses. $\mathrm{J}$ Neurosci 31:5235-5243.

Naidoo V, Dai X, Galligan JJ (2010) R-type $\mathrm{Ca}(2+)$ channels contribute to fast synaptic excitation and action potentials in subsets of myenteric neurons in the guinea pig intestine. Neurogastroenterol Motil 22:353-63.

Nave K-A, Trapp BD (2008) Axon-glial signaling the glial support of axon function. Annu Rrev Neurosci 31:535-61.

Oland LA, Pott WM, Bukhman G, Sun XJ, Tolbert LP (1996) Activity blockade does not prevent the construction of olfactory glomeruli in the moth Manduca sexta. Int J Dev Neurosci 14:983-96.

Oland LA, Tolbert LP. 1987. Glial patterns during early development of antennal lobes of Manduca sexta: A comparison between normal lobes and lobes deprived of antennal axons. J Comp Neurol 255:196-207.

Oland LA, Tolbert LP (1989) Patterns of glial proliferation during formation of olfactory glomeruli in an insect. Glia. 2:10-24.

Oland LA, Tolbert LP (2010) Roles of glial cells in neural circuit formation: Insights from research in insects. Glia. Dec 1. [Epub ahead of print]

Oland LA, Marrero HM, Burger I (1999) Glial cells in the developing and adult olfactory lobe of the moth Manduca sexta. Cell Tissue Res 297:527-45.

Oland LA, Pott WM, Higgins MR, Tolbert LP (1998) Targeted ingrowth and glial relationships of olfactory receptor axons in the primary olfactory pathway of an insect. J Comp Neurol 398:119-38.

Oland LA, Tolbert LP, Mossman KL (1988) Radiation-induced reduction of the glial population during development disrupts the formation of olfactory glomeruli in an insect. J Neurosci 8:35367.

Oland LA, Pott WM, Howard CT, Inlow M, Buckingham J (2003) A diffusible signal attracts olfactory sensory axons toward their target in the developing brain of the moth. J Neurobiol. 56:24-40. 
Peters A, Palay SL, Webster deF (1991) The Fine Structure of the Nervous System. $3^{\text {rd }}$ Ed. New York: Oxford University Press.

Piechotta K, Lu J, Delpire E (2002) Cation chloride cotransporters interact with the stress-related kinases Ste20-related proline-alanine-rich kinase (SPAK) and oxidative stress response 1 (OSR 1). J Biol Chem 297:50812-50819.

Rela L, Bordey A, Greer CA (2010) Olfactory ensheathing cell membrane properties are shaped by connectivity. Glia 58:665-678.

Rieger A, Deitmer JW, Lohr C (2007) Axon-glia communication evokes calcium signaling in olfactory ensheathing cells of the developing olfactory bulb. Glia 55:352-9.

Rodrigues F, Schmidt I, Klämbt C (2011) Comparing peripheral glial cell differentiation in Drosophila and vertebrates. Cell Mol Sci 68:55-69.

Rössler W, Oland LA, Higgins MR, Hildebrand JG, Tolbert LP (1999) Development of a gliarich axon-sorting zone in the olfactory pathway of the moth Manduca sexta. J Neurosci. 19:9865-77.

Sanes JR, Hildebrand JG (1976) Origin and morphogenesis of sensory neurons in an insect antenna. Dev Biol 51:300-319.

Sanes JR, Hildebrand JG (1975) Nerves in the antenna of pupal Manduca sexta (Lepidoptera:Sphingidae) W Roux’ Archiv 178:71-78.

Sanes JR, Prescott DJ, Hildebrand JG. (1977). Cholinergic neurochemical development of normal and deafferented antennal lobes during metamorphosis of the moth, Manduca sexta. Brain Research 119:389-402.

Sen A, Shetty C, Jhaveri D, Rodrigues V (2005) Distinct types of glial cells populate the Drosophila antenna. BMC Dev Biol 5:25.

Sepp KJ, Schulte J, Auld VJ (2000) Developmental dynamics of peripheral glia in Drosophila melanogaster. Glia. 30:122-33.

Schweitzer ES, Sanes JR, Hildebrand JG (1976) Ontogeny of electroantennogram responses in the moth, Manduca sexta. J Insect Physiol 22: 955-960.

Shih C-H, Hsu H-T, Wang K-H, Ko- W-C (2010) Calcium channel subtypes for cholinergic and nonadrenergic noncholinergic neurotransmission in isolated guinea pig trachea [NaunynSchmied] Arch Pharmacol 382:419-432.

Silies M, Edenfeild G, Engelen D, Stork T, Klambt C (2007) Development of peripheral glial cells in Drosophila. Neuron Glia Biol 3:35-43. 
Song CK, Johnstone LM, Schmidt M, Derby CD, Edwards DH (2007) Social domination increases neuronal survival in the brain of juvenile crayfish Procambarus clarkii. J Exp Biol 210:1311-1324

Stebbings, LA, Todman MG, Phillips R, Greer CE, Tam J, Phelan P, Jacobs K, Bacon JP, Davies JA (2002) Gap junctions in Drosophila: Developmental expression of the entire innexin gene family. Mech. Dev. 113: 197-205.

Stevens B, Fields RD (2000) Response of Schwann cells to action potentials in development. Science 287:2267-71.

Su Z, He C (2010) Olfactory ensheathing cells: Biology in neural development and regeneration. Prog Neurobiol 92: 517-532.

Thyssen A, Hirnet D, Wolburg H, Schmalzing G, Deitmer JW, Lohr C (2010) Ectopic vesicular neurotransmitter release along sensory axons mediates neurovascular coupling via glial calcium signaling. Proc Natl Acad Sci U S A 107:15258-63.

Tolbert LP, Hildebrand JG (1981) Organization and synaptic ultrastructure of glomeruli in the antennal lobes of the moth Manduca sexta: a study using thin sections and freeze-fracture. Proc R Soc Lond B 213:279-301.

Treloar HB, Purcell AL, Greer CA (1999) Glomerular formation in the developing rat olfactory bulb. J Comp Neurol 413:289-304.

Tucker ES, Tolbert LP (2003) Reciprocal interactions between olfactory receptor axons and olfactory nerve glia cultured from the developing moth Manduca sexta. Dev Biol 260:9-30.

van den Pol AN, Finkbeiner SM, Cornell-Bell AH (1992) Calcium excitability and oscillations in suprachiasmatic nucleus neurons and glia in vitro. J Neurosci. 12:2648-64.

von Hilchen CM, Beckervordersandforth RM, Rickert C, Technau GM, Altenhein B (2008) Identity, origin, and migration of peripheral glial cells in the Drosophila embryo. Mech Dev 125:337-352.

Von Hilchen CM, Hein I, Technau GM, Altenhein B (2010) Netrins guide migration of distinct glial cells in the Drosophila embryo. Development 137:1251-1262.

Waxman SG, Black JA (1995) Axoglial interactions at the cellular and molecular levels in central nervous system myelinated fibers. Neuroglia ,Chptr 40, Eds.: Kettenmann H, Ransom BR. Oxford, Oxford University Press, pp 587-610.

Wright JW, Copenhaver PF (2000) Different isoforms of fascicin II play distinct roles in the guidance of neuronal migration during insect embryogenesis. Dev Biol 225:59-78. 
Young SH, Poo MM (1983) Spontaneous release of transmitter from growth cones of embryonic neurones. Nature. 305(5935):634-637.

Zakharenko S, Chang S, O'Donoghue M, Popov SV (1999) Neurotransmitter secretion along growing nerve processes: comparison with synaptic vesicle exocytosis. J Cell Biol. 144(3):50718. Erratum in: J Cell Biol (1999) 144:following 801.

Zufall F, Stengl M, Franke C, Hildebrand JG, Hatt H (1991) Ionic currents of cultured olfactory receptor neurons from antennae of male Manduca sexta. J Neurosci 4: 956-965. 